\title{
Fiscal Consolidation in Southeastern European Countries: The Role of Budget Institutions
}

Brian Olden, Duncan Last, Sami Yläoutinen, Carla Sateriale 


\title{
IMF Working Paper
}

Fiscal Affairs Department

\section{Fiscal Consolidation in Southeastern European Countries: The Role of Budget Institutions \\ Prepared by Brian Olden, Duncan Last, Sami Yläoutinen, Carla Sateriale ${ }^{1}$}

Authorized for distribution by Marco Cangiano

May 2012

\section{This Working Paper should not be reported as representing the views of the IMF.} The views expressed in this Working Paper are those of the author(s) and do not necessarily represent those of the IMF or IMF policy. Working Papers describe research in progress by the author(s) and are published to elicit comments and to further debate.

\begin{abstract}
This paper assesses the relative strengths and weaknesses of fiscal institutions in ten Southeastern European countries, using recent benchmarking methodologies developed by FAD. The assessment evaluates each country's understanding of the scale of the fiscal adjustment challenge, its ability to develop a credible consolidation strategy, and its capacity to implement the strategy. Key institutional arrangements, are generally in place, including topdown budgeting and medium-term budget frameworks. Other institutional arrangements require further attention, including macro-fiscal forecasting, fiscal risk analysis, setting fiscal objectives, presence and role of independent fiscal agencies, and top-down parliamentary approval.
\end{abstract}

JEL Classification Numbers: H60, H61, H68

Keywords: $\quad$ Southeastern Europe, Fiscal Consolidation, Budget Institutions

Authors’ E-Mail Addresses: bolden@imf.org; dlast@imf.org; sylaoutinen@imf.org; csateriale@imf.org

\footnotetext{
${ }^{1}$ This paper builds on a 2010 work by Guilhem Blondy, Richard Hughes, Ian Lienert, and Goesta Ljungman which presented the findings from a cross-country review of budget institutions across G-20 countries, a project coordinated by Marco Cangiano and Michel Lazare. An earlier version of this paper was presented at a European Commission DG ECFIN Workshop on "Public Finances in Times of Severe Economic Stress-The Role of Institutions" on November 30, 2011.
} 
Abstract 1

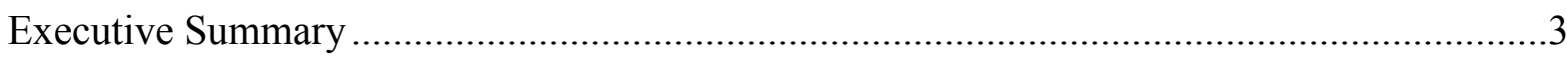

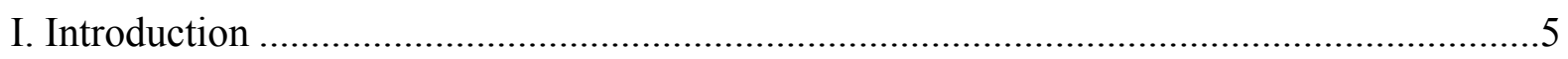

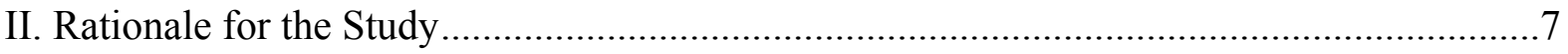

III. Institutional Determinants of Effective Consolidations........................................... 9

A. Understanding the Scale and Scope of the Fiscal Challenge ...............................10

B. Developing a Credible Fiscal Consolidation Strategy ..........................................13

C. Implementing the Consolidation Strategy through the Budget Process..................17

IV. Evaluation of Budget Institutions in SouthEastern European Countries..........................19

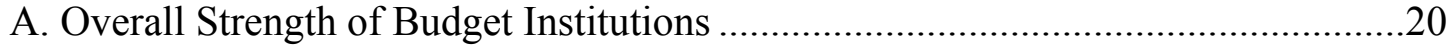

B. Overall Institutional Strength versus Consolidation Required............................24

C. Understanding the Fiscal Challenge .................................................................25

D. Developing a Consolidation Plan....................................................................28

E. Implementing the Consolidation Strategy ..................................................... 31

V. Strengthening Budgetary Institutions in Southeastern European Countries ......................34

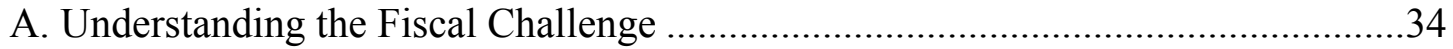

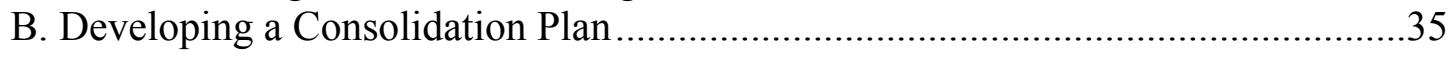

C. Implementing the Consolidation Strategy …...................................................

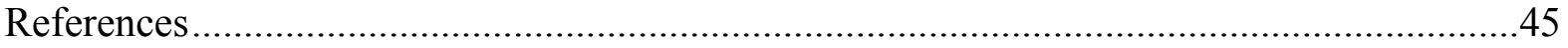

Tables

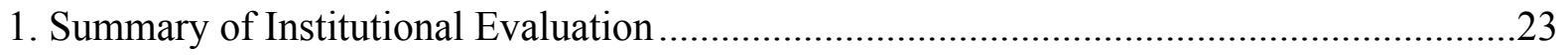

2. Understanding the Fiscal Challenge .......................................................................27

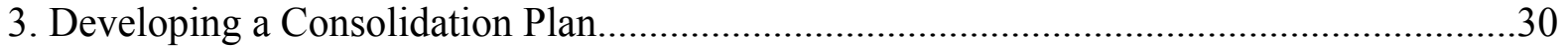

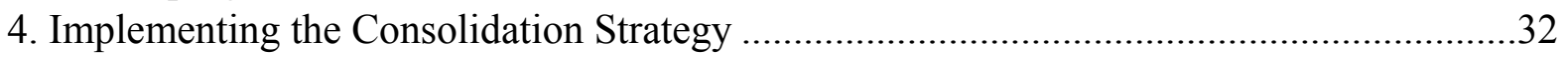

Figures

1. Deficit and Debt Trends in Southeastern European Countries-2001-11 ...........................6

2. Average Scores - Southeastern Europe Versus Selected EU Countries............................21

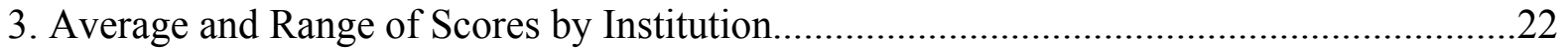

4. Strength of Budget Institutions versus Fiscal Adjustment Required ...............................25

Boxes

1. Ten Budget Institutions for Fiscal Consolidation ..................................................

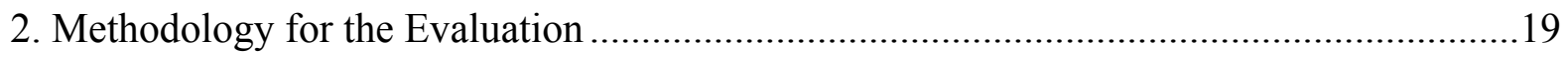

Appendixes

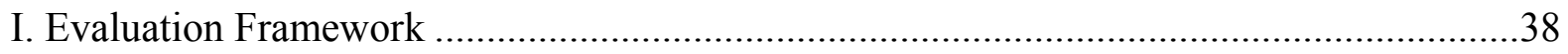




\section{EXECUTIVE SUMMARY}

Fiscal policy-making and the institutions that support it in the ten Southeastern European countries surveyed in this paper ${ }^{2}$ have been severely tested during the current global financial crisis. From an initial emphasis on stabilizing financial markets, stimulating economic activity, and stemming the rise in unemployment, the focus of fiscal policy has now turned to the challenges of consolidating public finances and restoring long-term sustainability. The theoretical and empirical literature both suggest that well-designed and efficiently managed budget institutions can play a central role in the success of fiscal consolidations.

This paper identifies ten fiscal institutions that can support the fiscal consolidation process at three key stages: (i) understanding the scale and scope of the fiscal challenge; (ii) developing a credible consolidation strategy; and (iii) implementing that strategy through the budget process. ${ }^{3}$ The paper then evaluates the institutional preparedness of Southeastern European countries to respond to fiscal challenges and identifies priorities for institutional reform.

Individual countries show great variations in terms of the strength of the ten institutions. This within-country variation is greater than the overall variation across countries. Hence, there is room for improvement in all countries. The analysis presented in the paper highlights the priorities for institutional reform to support the fiscal consolidation required in the ten countries.

Improvements in the breadth, depth, and timeliness of fiscal reporting and more systematic analysis of the risks surrounding fiscal forecasts would contribute to better understanding of the scale and scope of the fiscal challenges. While basic fiscal reporting is in place in virtually all Southeastern European countries, less than complete coverage of institutions and transactions, and long reporting lags reduce its impact on policy-making in many countries. Multi-year macroeconomic and fiscal forecasts are the norm but tend to be limited to a single scenario. Although fiscal risks are increasingly being disclosed, quantification and control are typically limited to explicit guarantees and tend to ignore implicit guarantees and contingent liabilities.

\footnotetext{
${ }^{2}$ Albania, Bosnia and Herzegovina, Bulgaria, Croatia, Kosovo, Macedonia FYR, Moldova, Montenegro, Romania, and Serbia.

${ }^{3}$ The expression "fiscal institutions" refers to the organizational and procedural arrangements through which decisions on fiscal matters are taken, or which provide input into such decision-making. In the context of this paper, the ten fiscal institutions are: I. Understanding the scale and scope of the fiscal challenge - (i) fiscal reporting, (ii) macroeconomic and fiscal forecasting, (iii) fiscal risk disclosure and management; II. Developing a credible fiscal consolidation strategy - (iv) medium-term fiscal objectives, (v) medium-term budget frameworks, (vi) independent fiscal agencies, (vii) performance orientation; III. Implementing the consolidation strategy - (viii) top-down budgeting, (ix) parliamentary budget approval, and (x) budget execution.
} 
Consolidation planning needs to be supported by more clearly articulated fiscal objectives, more comprehensive and binding medium-term budget frameworks, greater independent scrutiny, and a stronger focus on performance. While most Southeastern European countries set medium-term objectives for fiscal policy, these are not often formulated and monitored in a manner which enables the public to hold the government to account for their realization. Medium-term budget frameworks are in place in nearly all countries but need to be expanded in coverage and impose more binding constraints on future budgets. Independent fiscal agencies providing input into fiscal policy-making remain uncommon in Southeastern Europe. While all Southeastern European countries have introduced elements of performance budgeting, performance information needs to be more systematically integrated into budget decision-making processes in most countries.

Finally, implementation of consolidation plans would benefit from a more rigorous top-down approach to budgeting, stronger parliamentary endorsement of consolidation strategies, and more explicit contingency arrangements. Budget preparation follows a top-down approach in most Southeastern European countries to a degree, but budgetary rigidities and circumvention of the budget process diminish its disciplining impact. Parliamentary ownership of the government's fiscal strategy is limited by a traditional bottom-up, chapterby-chapter approach to budget approval in most countries. While controls over budget execution are relatively strong, management of contingency reserves and controls on multiyear spending commitments need to be strengthened in order to keep consolidation plans on track. 


\section{INTRODUCTION}

1. As in most countries, the economies and public finances of Southeastern Europe (SEE) have been affected by the global economic crises. Looking ahead, medium-term fiscal policy in all countries needs to focus on ensuring fiscal sustainability, bearing in mind the fragile nature of the economic recovery and the need to implement key structural reforms to address longer-term fiscal challenges, such as demographic changes and increasing agerelated expenditures.

2. This paper identifies budgetary institutions that can support fiscal consolidation, and assesses the institutional preparedness of Southeastern European countries for the fiscal challenges ahead. ${ }^{4,5}$ Restoring stability and sustainability to public finances will be a priority in coming years in many Southeastern European countries, and there is evidence that certain institutional arrangements can greatly enhance fiscal rigor. This suggests that governments should also, as part of the consolidation strategy, consider the adequacy of the structures, rules and procedures that govern the formulation, passage, and execution of their budgets. Reforms in institutional framework can not only improve fiscal discipline in general but also increase the probability of successful consolidation.

\section{The paper reviews ten budgetary institutions that can support Southeastern} European countries' consolidation efforts at three key stages of the fiscal policy-making process: (i) understanding the scale and scope of the fiscal challenge; (ii) developing a credible fiscal consolidation strategy; and (ii) implementing that strategy through the budget process. The paper goes on to provide an evaluation of the Southeastern European countries' institutional preparedness for fiscal consolidation. It then concludes with a set of recommendations about the key institutional reforms that could increase the changes of successful fiscal consolidations in the Southeastern European region.

4. The paper is structured as follows. Section II provides the rationale for the study. Section III identifies key budgetary institutions supporting fiscal consolidation. Section IV summarizes the findings of an assessment of Southeastern European countries against this framework. Finally, Section V discusses priorities for institutional reforms. Appendix I presents the full institutional framework.

\footnotetext{
${ }^{4}$ The study draws from a series of papers prepared by IMF staff on the impact of, response to, and exit from the current economic, financial, and fiscal crisis. See, for example, IMF (2009a), Cottarelli and Viñals (2009), IMF (2010a, 2011a, 2011b).

${ }^{5}$ The factual information underpinning these country evaluations was validated with participants at an FAD fiscal institutions seminar for Southeastern European countries held in Ljubljana, Slovenia in June 2011. The results should nevertheless be treated as provisional until officially confirmed with country authorities.
} 
6

Figure 1. Deficit and Debt Trends in Southeastern European Countries-2001-11 ${ }^{6}$

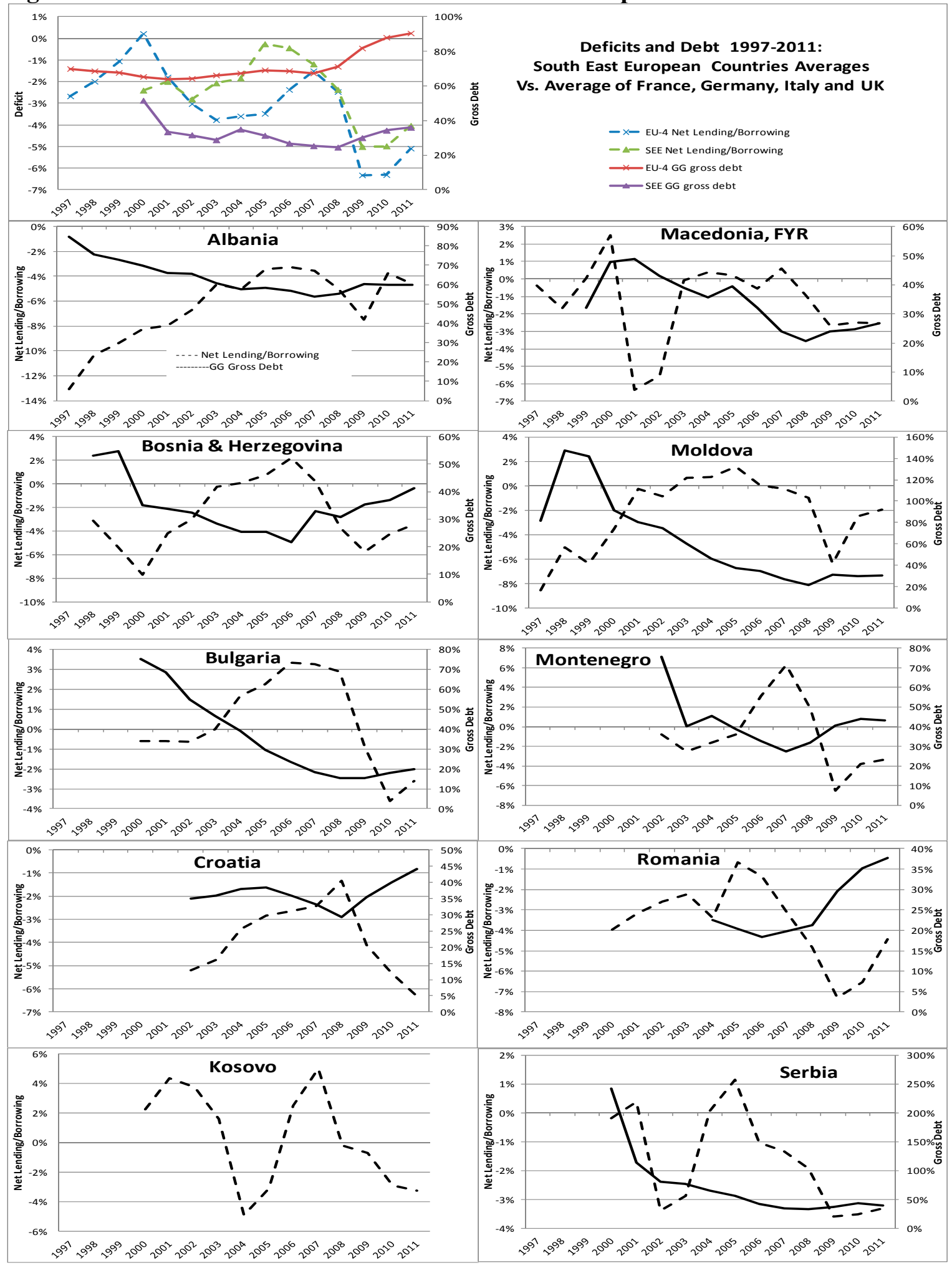

${ }^{6}$ Coverage is general government. Source WEO. 


\section{RATIONALE FOR THE STUDY}

5. A well established body of theoretical and empirical analysis shows that budgetary institutions help shape fiscal outcomes. ${ }^{7}$ Strong institutions can improve fiscal performance by highlighting the need for sustainable policies, exposing the full cost of public interventions, emphasizing collective responsibility over sectoral interests, and raising the cost of deviating from stated fiscal objectives. Robust institutions are particularly important during a period of fiscal retrenchment, when the tension between short-term sectoral interests and long-term collective aims are often at their highest. By increasing the credibility of announced policies, strong institutions can also foster more favorable macroeconomic conditions, such as lower interest rates, lower inflation expectations, and improved market confidence, which further support the restoration of fiscal sustainability. Of course, the institutional framework cannot substitute for a lack of commitment by the government or the society at large to restoring rectitude in public finances. Fiscal reports can be manipulated, fiscal rules can be circumvented, budgetary regulations and procedures can be changed, and consolidation plans can be ignored. Nevertheless, a strong institutional framework makes it more difficult to deviate from appropriate policies.

6. This study focuses on Southeastern European countries, where basic budget institutions have undergone significant reform over the last decade. The purpose is not to replicate other guidelines, diagnostic tools, or surveys, such as the IMF's Manual on Fiscal Transparency, the Public Expenditure and Financial Accountability framework, or the OECD's Budget Practices and Procedures survey. Rather, this paper focuses on a subset of budgetary institutions that could support fiscal consolidation in Southeastern European countries.

\section{The selection of budget institutions is also influenced by five features of the} current global crisis and its fiscal impact on Southeastern European economies:

- $\quad$ First, the scale of the fiscal challenge facing Southeastern European countries is significant with most countries facing fiscal adjustments far greater than their medium-term projections have allowed for. Institutional arrangements supporting significant reorientations of fiscal policies are needed.

- $\quad$ Second, the array of government interventions undertaken to stabilize the financial system and stimulate economic activity are more complex than in the past. ${ }^{8}$ Fiscal

\footnotetext{
${ }^{7}$ A positive causality between the quality of budget institutions and fiscal outcomes has been demonstrated in numerous studies covering countries with different income levels, constitutional systems, and geographical locations. See, for example, von Hagen (1992), von Hagen and Harden (1996), Alesina et al. (1999), de Haan et al. (1999), Gleich (2003), and Hallerberg et al (2009).

${ }^{8}$ See IMF (2009b, 2010a, and 2010b) for a detailed discussion of the size and composition of fiscal stimulus measures in $\mathrm{G}-20$ countries.
} 
reporting arrangements that provide a thorough picture of interventions and their respective medium-term implications are crucial to effective consolidation planning.

- $\quad$ Third, the policy response to the crisis has engaged a range of public sector institutions. In many countries, public financial institutions, state-owned enterprises, and central banks have played a role in supporting financial stability. Sub-national governments have seen a decline in revenues, while also being a conduit for central government fiscal stimulus measures. Budget institutions must, therefore, take a broad approach to strengthening public sector finances, including risks associated with the expansion of government assets and liabilities.

- Fourth, the risks to the macroeconomic and fiscal outlook for Southeastern European countries remain considerable. While financing needs are more moderate for emerging economies, including countries in Southeastern Europe, than has been the case in many OECD countries, they are by no means negligible. In addition, countries in the region may face spillover shocks in the event that the international situation deteriorates further. Other risks include political constraints that may prevent the necessary fiscal adjustment from taking place. A further source of risk, although less of an immediate concern, could be the resurgence of volatile international capital flows to the region, tempted by the search for higher yields that could recreate some of the conditions that led to the current crisis.

- $\quad$ Fifth, at least in some countries, the crisis has weakened confidence in the economic and fiscal policy-making arrangements that helped to maintain stability in the precrisis period. Some governments, therefore, face the added challenge of rebuilding fiscal credibility. Institutional reform can help to signal a government's commitment to fiscal sustainability and should be considered as an integral part of the broader consolidation plan.

8. Some institutional considerations relevant to the process of fiscal consolidation are, however, outside the scope of this paper:

- $\quad$ The paper is confined to aspects of fiscal governance that the government and parliament can realistically influence within a time period of a few years. Political or constitutional institutions such as the form of government or the nature of the electoral system — although also relevant to fiscal outcomes - are not analyzed.

- $\quad$ Only formal institutions that are both readily identifiable and have a verifiable impact on fiscal decision-making are included in this assessment. Established conventions, traditions, and unwritten rules are not considered.

- $\quad$ The study focuses on institutions that are independent of the wider political landscape. Factors such as the relative strength of the finance minister or the political 
orientation of the government can have an impact on fiscal performance but are outside the scope of this study.

- Several studies link the success of fiscal consolidation to structural reforms of the labor market, civil service, and pension systems. These non-budgetary institutions are outside the scope of this study.

- $\quad$ Finally, high standards of transparency and accountability cut cross all of the identified budgetary institutions, and are not considered separate institutions per se. ${ }^{9}$

\section{InSTITUTIONAL DETERMinANTS OF EFFECTIVE CONSOLIDATIONS}

9. This section identifies ten budgetary institutions (Box 1) that can support Southeastern European countries' consolidation efforts at three key stages of the fiscal policy-making process:

- $\quad$ understanding the scale and scope of the fiscal challenge;

- $\quad$ developing a credible fiscal consolidation strategy; and

- $\quad$ implementing that strategy through the budget process.

\section{Box 1. Ten Budget Institutions for Fiscal Consolidation}

A. Understanding the Scale and Scope of the Fiscal Challenge

1. Fiscal Reporting

2. Macroeconomic and Fiscal Forecasting

3. Fiscal Risk Disclosure and Management

B. Developing a Credible Fiscal Consolidation Strategy

4. Medium-term Fiscal Objectives

5. Medium-term Budget Frameworks

6. Independent Fiscal Agencies

7. Performance Orientation

C. Implementing the Consolidation Strategy

8. Top-down Budgeting

9. Parliamentary Budget Approval

10. Budget Execution

\footnotetext{
${ }^{9}$ See IMF Manual on Fiscal Transparency (2007).
} 
10. The institutions included in the framework have been identified on the basis of their ability to increase the probability of a successful consolidation. This has an impact on both the choice of institutions and the characteristics that are highlighted under each institution (Appendix I). Nevertheless, a strong institutional framework has a broader function of fostering fiscal sustainability, and will be equally important after the initial consolidation effort has been achieved. As the impact of, and response to, the crisis, together with the underlying long-term challenges, differ substantially across Southeastern European countries, the emphasis on various institutions will also differ between countries. The linked and mutually reinforcing nature of the different institutions also underlines the importance of taking a comprehensive approach to institutional reform. The framework should, therefore, not be perceived as a generic guide to the sequencing of reform priorities, which will depend on country specific circumstances.

\section{A. Understanding the Scale and Scope of the Fiscal Challenge}

11. Full awareness of the current state and future evolution of the public finances is critical to the initiation and delivery of a fiscal consolidation program. As many countries face a complex and uncertain macroeconomic and fiscal outlook, there is a risk of underestimating the full fiscal challenge, and hence the necessary adjustment. ${ }^{10}$ Fiscal reporting arrangements that provide decision makers and the public with accessible, credible, and transparent information are central to building and sustaining public support for tough and potentially unpopular measures. In this context, the following institutions are important:

- $\quad$ comprehensive, timely, and credible fiscal reporting;

- $\quad$ robust macroeconomic and fiscal forecasting; and

- full disclosure and prudent management of fiscal risks.

\section{Comprehensive, timely, and credible fiscal reporting}

12. The government's annual financial statements need to be comprehensive and timely to provide an effective basis for consolidation planning. End-year accounts covering all of central government, including any extra-budgetary arrangements, centrally administered social security funds or government-controlled corporations, should be available soon after the end of the fiscal year to allow them to inform the preparation of next year's budget. ${ }^{11}$ Similar coverage is also required of local government end-year accounts. In

\footnotetext{
${ }^{10}$ European Commission (2010), OECD (2007a) and Guichard et al. (2007) find that countries facing an unfavorable outlook with a high deficit and debt have a higher success rate in their consolidations.

${ }^{11}$ IMF (2007) and OECD (2004) both prescribe that statements should be available within six months.
} 
the context of the current crisis, coverage of transactions between governments and public and private sector financial institutions are especially relevant and should be reflected in both government accounts and financial statistics (see \# 14). ${ }^{12}$

13. To adequately reflect complex financial transactions, the government's annual financial statements should also incorporate accrual concepts and include a comprehensive balance sheet. A full presentation of all asset and liability holdings enables a more thorough understanding of how the government's fiscal position has changed with crisis intervention measures. External audit and certification - with an emphasis on reconciliation of stocks and flows to limit the scope for inconsistencies or creative accounting - also ensures that decision makers have access to fiscal reports of high quality. ${ }^{13}$

\section{Comprehensive and high quality national accounts statistics are also important} to promoting understanding of the impact of the government's consolidation strategy on the public sector finances and the wider economy. Government financial statistics need to cover general government to ensure a comprehensive picture of both central and local government finances. In instances where public corporations or the central bank have played a prominent part in the crisis response, statistics should ideally cover the entire public sector. Statistics should be produced by an independent statistics office, presented in line with internationally recognized and harmonized standards,,$^{14}$ so as to ensure their credibility, quality, timeliness, and comparability.

\section{Robust macroeconomic and fiscal forecasting}

15. The formulation of an effective fiscal consolidation strategy also requires a clear understanding of the medium-term outlook. Detailed multi-year macroeconomic and fiscal forecasts, updated at least twice a year, are important to ensure that budget decisions are informed by an up-to-date assessment of fiscal prospects. Separately identifying the impact of new policy measures enables the public to judge whether they represent an adequate response to fiscal challenges and hold government to account for their delivery. ${ }^{15}$

16. Ageing populations, climate change, and other structural challenges also have an impact on the consolidation strategy. Attempts to deal with the aftermath of the current

\footnotetext{
${ }^{12}$ IMF (2009a) emphasizes transparent reporting of government interventions in the financial sector as a key precondition to understanding the fiscal position in crisis countries and developing appropriate policy responses.

${ }^{13}$ Milesi-Ferretti and Moriyama (2004) and Balassone et al. (2007) show that creative accounting aimed at presenting a better-than-actual fiscal position increases during times of fiscal pressure (such as in the run up to EU accession), and that it often takes the form of inconsistent treatment of stocks and flows.

${ }^{14}$ IMF's Government Finance Statistics (GFS), the UN's System of National Accounts (SNA), and Eurostat's European System of Accounts (ESA).

${ }^{15}$ See European Commission (2008) pp. 109-115 for a discussion of making a no-policy-change assessment.
} 
crisis and these longer-term issues sequentially may lead to consolidation fatigue with a diminished chance of success. Reports on fiscal developments covering 30 years, 50 years, or even more, are for many countries, important to ensure that adjustments are sufficiently ambitious to address longer-term sustainability concerns. Given the substantial uncertainties involved in making long-term projections, such projections need to take into account a wide range of exogenous factors and consider alternative scenarios. ${ }^{16}$

\section{Fiscal risk disclosure and management}

\section{A government's consolidation strategy needs to be robust to the risks that} threaten the fiscal position. ${ }^{17}$ The current crisis has underlined the breadth and scale of potential calls on the public purse and the need for comprehensive monitoring and management of fiscal risks. Going forward, the case becomes even stronger, as there is a tendency to circumvent expenditure restrictions by resorting to guarantees and other contingent liabilities in times of fiscal stress. Budget documentation is strengthened by the identification of all contingent claims on the government. ${ }^{18}$ By subjecting new contingent liabilities to the same scrutiny and approval as regular budget appropriations, more stringent fiscal discipline can be achieved.

\section{In light of current economic and financial uncertainties, it is important to} demonstrate the robustness of fiscal plans to changes in forecast assumptions and in the value of the government's asset and liability holdings. Presenting alternative macroeconomic scenarios and assessing their impact on the fiscal position, allows the credibility of the proposed return to sustainability to be scrutinized. Some countries now face large fiscal risks associated with valuation losses from acquisition of financial sector assets. These risks should be analyzed, estimated, and presented as part of a comprehensive framework for the management of public assets and liabilities.

\section{Comprehensive monitoring and control of tax expenditures protects the} consolidation plan from a major source of fiscal risk during consolidation periods. The growth of tax expenditures - i.e., deviations from established tax norms or benchmarks, intended to provide a benefit for a specific activity or class of taxpayer-has been a source of fiscal leakage during consolidation periods, as governments and legislatures seek to

\footnotetext{
${ }^{16}$ IPSAS Board recently proposed that reports on the long-term sustainability of public finances become part of government reporting obligations (IPSASB, 2009).

${ }^{17}$ See IMF (2005) for a comprehensive discussion of fiscal risks, and Everaert et al. (2009) for a discussion of post-crisis fiscal risk management. See IMF (2007) for reporting arrangements of contingent liabilities.

18 These could include government guarantees, various types of government insurance arrangements, and legal claims against the government.
} 
circumvent institutional constraints on spending. Tax expenditures should, therefore, be identified and, as far as possible, quantified and controlled as part of the annual budget. ${ }^{19}$

\section{B. Developing a Credible Fiscal Consolidation Strategy}

20. Cross-country analysis of successful fiscal adjustments holds lessons for both the design of effective consolidation strategies and the institutions that can support them. Recent panel studies found that successful consolidations tend to take a medium-term perspective, start from credible macroeconomic assumptions, contain a significant expenditure component, and take a targeted approach to expenditure rationalization. ${ }^{20} \mathrm{To}$ support the development of consolidation strategies that have these characteristics, the following four budget institutions have been shown to be instrumental:

- $\quad$ medium-term fiscal objectives;

- $\quad$ medium-term budget frameworks;

- $\quad$ independent fiscal agencies; and

- $\quad$ performance-oriented budgeting.

\section{Medium-term fiscal objectives}

21. Comprehensive, stable, and transparent medium-term fiscal objectives, against which the government can be held accountable, provide a stable anchor for present and future policy decisions and raise the costs of deviating from the consolidation path. However, the impact of such objectives on actual fiscal policy decisions is closely linked to the perceived cost of noncompliance. For this reason, it is central that objectives are precise in terms of the targeted numerical value, that the time-frame over which they apply is unambiguously defined, and that there is regular public reporting of the actual outturn against the objectives. In addition, the coverage of these medium-term objectives should be comprehensive to ensure that they address the sustainability of the entire general government sector. Local governments should be subject to clear fiscal regulations, backed by credible enforcement mechanisms. ${ }^{21}$

\section{Formalizing these medium-term fiscal objectives as permanent fiscal rules can} signal a strong commitment to fiscal discipline, which, provided that certain preconditions are in place, can support the consolidation effort. However, empirical studies

\footnotetext{
${ }^{19}$ IMF (2007) and OECD (2004) discuss good practice in accounting for and controlling tax expenditures.

${ }^{20}$ See European Commission (2010), OECD (2007b), Tsibouris et al. (2006), and Gupta et al. (2005).

${ }^{21}$ See Kopits and Symansky (1998), IMF (2009c), and European Commission (2010) for a discussion of design choices in fiscal rules and objectives.
} 
show that fiscal rules have been more important in sustaining the pace of consolidations that were already underway than in prompting the initial turnaround in fiscal fortunes. ${ }^{22}$ This suggests that existing fiscal rules can have a positive impact, but that the timing of adopting new fiscal rules needs to take into account the level of consolidation required and degree of uncertainty around future prospects. Once adopted, medium-term fiscal frameworks need to allow for uncertainty about underlying economic prospects (through, for example, targets that are cyclically adjusted or averaged over a period of more than one year) and provide some scope for counter-cyclical policy action (through, for example, the exclusion from multi-year expenditure limits of a limited number of cyclically-sensitive expenditure items, such as unemployment benefits).

\section{Medium-term budget frameworks}

23. A credible medium-term budget framework is crucial to meeting aggregate fiscal objectives and achieving consolidation success. A medium-term budget framework consists of arrangements for formulating and presenting projections of individual revenue and expenditure items; fixing binding multi-year restrictions on expenditure aggregates; and providing clear indications of policy priorities that stretch beyond the annual budget horizon. A medium-term budget framework supports consolidation planning and delivery by:

- $\quad$ encouraging long-term planning by identifying the future impact of existing polices and new decisions and reducing the propensity for budget actors to wait-and-see what the crisis implies for them;

- $\quad$ enabling a more ambitious rationalization of expenditure by abstracting from the legal, administrative, and practical constraints that impinge upon the annual budget process; and

- $\quad$ reinforcing multi-year discipline by raising the reputational costs of slippages against the government's spending plans.

24. The empirical support for the effectiveness of medium-term budget frameworks in promoting fiscal discipline is strong but the success rate seems to be higher for advanced countries, ${ }^{23}$ and with impact being higher now than in the past. ${ }^{24}$ This

\footnotetext{
${ }^{22}$ IMF (2009c), Debrun et al. (2008), Guichard et al. (2007), European Commission (2007), Hallerberg et al. (2004); and European Commission (2006).

${ }^{23}$ European Commission (2010) emphasizes the link between medium-term frameworks and fiscal performance in the EU. Yläoutinen (2004) also found evidence of such links in Central and Eastern European countries during 2000s, following an earlier period of weaker links most likely attributable to the impact of the transition process on the public finances of these countries. Hallerberg and Yläoutinen (2010) confirm the link between fiscal governance and fiscal outcomes in these countries.
} 
underlines the need to pay attention to specific design features, as well as supporting institutions such as forecasting, accountability, and control arrangements. A credible and viable medium-term budget framework should provide:

- $\quad$ a detailed picture of the evolution of each major revenue and expenditure item beyond the budget year;

- $\quad$ a binding multi-year restriction on aggregate expenditure whose value remains independent of expenditure forecast revisions, ${ }^{25}$

- $\quad$ a statement of the government's medium-term sectoral priorities, through a presentation of planned expenditure by budget chapter or ministry; and

- the broadest possible coverage of central government revenue and expenditure. ${ }^{26}$

\section{Independent fiscal agencies}

\section{Independent fiscal agencies can help to support the overall credibility of a} government's consolidation plan. ${ }^{27}$ Independent fiscal agencies are publicly funded bodies with significant professional independence from the government, providing analysis and/or recommendations in the area of fiscal policy on a regular basis. ${ }^{28}$ Such agencies can support the consolidation process in a number of ways. First, relinquishing some or all responsibility for macroeconomic or fiscal forecasting to an independent body, or asking it to validate the government's assumptions, can help to inject greater realism into budget plans and address the observed bias toward optimism in official forecasting. ${ }^{29}$ Second, independent agencies can support the credibility of the consolidation process by scrutinizing the government's consolidation plans. Third, an independent agency can be tasked with evaluating the

\footnotetext{
${ }^{24}$ While von Hagen (1992) did not find that long-term constraints improved fiscal performance for EU-member states, this relationship was established when the study was repeated by Hallerberg et al. (2004), explained by the introduction of multiannual frameworks supporting such constraints in the 1990s.

${ }^{25}$ European Commission (2007) finds that the articulation of a fixed spending path promotes fiscal discipline.

${ }^{26}$ That a wide coverage of the medium-term budget framework increases fiscal discipline, is supported by European Commission (2006) and de Haan et al. (1999).

${ }^{27}$ European Commission (2006 and 2007) and Debrun et al. (2009) find a positive relationship between the presence of a fiscal council and fiscal outcomes.

${ }^{28}$ Calmfors and Wren-Lewis (2011), Rogoff and Bertelsmann (2010), Debrun et al. (2009), Wyplosz (2008), and Jonung and Larch (2004) discuss the role of independent fiscal agencies.

${ }^{29}$ Larch and Salto (2005) and Jounung and Larch (2004) find strong evidence of such a optimistic bias. Strauch et al. (2004) find that optimistic bias was more apparent during the Maastricht convergence process and that particularly those governments where budgetary targets are based on pre-negotiated contracts seem to have a cautionary bias. European Commission (2007) and Jonung and Larch (2006) demonstrate that the optimistic bias can be traced to weak institutions.
} 
government's ex post performance against its fiscal objectives and rules, thereby raising the reputational costs to the government of any deviation from its announced consolidation path. A clearly defined mandate of such an agency should ensure that it supports, rather than conflicts with, the central fiscal authority.

\section{Performance orientated budgeting}

26. Performance budgeting-defined as the procedures that strengthen the links between the funds provided to public entities and their outcomes or outputs-can have a positive impact on fiscal consolidations in three main ways: ${ }^{30}$

- $\quad$ First, any expenditure-driven fiscal consolidation entails politically difficult decisions about public priorities, and performance information can help to mobilize the necessary support for such decisions.

- Second, maintaining public support for a consolidation program also depends on the government's ability to target non-priority sectors and protect socially sensitive areas. ${ }^{31}$ A prioritization that proceeds program-by-program — rather than by economic line item-by-line item — has a better prospect of achieving this.

- Finally, ambitious consolidation measures have to be absorbed by the administration without unacceptable consequences for the delivery of public services. Accountability for results rather than the detailed expenditure composition, allows for a devolution of managerial flexibility, facilitating an adaptation to tighter overall budget constraints. ${ }^{32}$

\section{A comprehensive program classification of the government sector, with clear} program objectives and targets, facilitates a discussion of how the budget contributes to the government's overall policies and the impact of various consolidation measures. Budgets should therefore be classified, and ideally appropriated, on a program basis. By defining and systematically monitoring a set of objectives and targets for each major expenditure program, nonfinancial effects of proposed consolidations measures can be brought into the discussion.

\footnotetext{
${ }^{30}$ European Commission (2007) finds performance budgeting to be associated with successful consolidation. Reddick (2003) and Crain and O'Roark (2004) find a positive impact of performance budgeting on aggregate fiscal performance, but, as pointed out by Robinson and Brumby (2005) the causality is unclear in these studies.

${ }^{31}$ Perotti (1998) and Wagschal and Wenzelburger (2008) underline the importance of protecting socially sensitive expenditure to sustaining consolidation effort.

${ }^{32}$ Such a link is emphasized by Robinson (2007). However, as pointed out by OECD (2007), enhancing the control over results has not been accompanied by delegation of managerial flexibility in all countries.
} 
28. Because simply generating performance information is rarely sufficient to ensure that it influences budget decisions, systematic performance reviews can provide an important input into the formulation of a well-targeted consolidation program. Although it is rarely possible to establish a direct link between performance and funding, performance information should feed into the budget process. Comprehensive reviews which evaluate the effectiveness of major government spending programs can help to provide a strong evidence base for expenditure rationalization. ${ }^{33}$

\section{Implementing the Consolidation Strategy through the Budget Process}

29. Even the most robust consolidation plan can be derailed when confronted with the pressures and realities of the annual budget process. Unless supported by strong institutional arrangements for the preparation, approval, and execution of the budget, there is a risk that actual expenditure will turn out to be higher than forecast, or actual revenue lower than forecast. Three elements are central in this regard:

- $\quad$ a top-down approach to budget preparation;

- $\quad$ constraints on parliamentary budget approval; and

- discipline in budget execution.

\section{A top-down approach to budget preparation}

30. Following a top-down approach to budget preparation increases the likelihood that the outcome of annual budget discussions will be consistent with the government's ex ante fiscal objectives and consolidation plan. ${ }^{34} \mathrm{~A}$ top-down approach to budgeting implies that a binding decision on budget aggregates is taken before an allocation of expenditure is made within those aggregates. Provided that previous decisions are respected throughout the preparation and execution of the budget, a top-down approach can foster fiscal discipline. This requires both broad political support for aggregate expenditure restrictions and realistic allocations which are consistent with those restrictions.

\section{To be effective in engendering fiscal discipline, a top-down budget process also} needs to be comprehensive. In implementing the consolidation plan, all central government revenue and expenditure should be included for discussion. Extensive ear-marking

\footnotetext{
${ }^{33}$ See OECD (2005b) and Curristine (2007) for a discussion of the role of expenditure reviews in performance budgeting.

${ }^{34}$ For a comprehensive review, see Ljungman (2009).
} 
arrangements or the proliferation of fiscal decisions outside the annual budget preparation process reduce the effectiveness of a top-down approach. ${ }^{35}$

\section{Constraints on parliamentary budget approval}

32. Legislatures can play an instrumental role in the consolidation process if they are engaged in setting the overall fiscal strategy. While parliament's formal powers over the allocation of public resources varies greatly across countries, experience suggests that pre-budget or budget orientation debates can help create parliamentary ownership of medium-term fiscal objectives in a range of legislative contexts. The political legitimacy of the overall fiscal strategy is further enhanced when parliament endorses the government's medium-term fiscal objectives before considering the government's annual budget proposal. ${ }^{36}$

33. However, greater parliamentary input into the overall fiscal strategy needs to be combined with legislative procedures that promote collective responsibility for its delivery. As in cabinet, voting on the budget in parliament should follow a top-down sequence in which the legislature first approves the main fiscal aggregates, such as the budget balance, total expenditure and total revenue, before voting the allocation of resources to different sectors, ministries, programs, or line items. The legislature can also limit possible deficit bias by restricting its own power to amend the government's draft budget. ${ }^{37}$

\section{Discipline in budget execution}

34. Effective implementation of a consolidation program requires budget execution procedures that maintain overall fiscal discipline, while recognizing that unexpected events will occur during the course of the budget year. Open-ended or standing appropriations should be kept to a minimum. Overspending against budget totals should require the government to introduce a supplementary budget and, ideally, propose offsetting expenditure cuts in order to keep overall spending within the MTBF limits set at budget time. ${ }^{38}$ Carry-over of expenditure - enabling budget agencies to exceed annual appropriations - should also be subject to restrictions. However, such restrictions need to strike a balance between encouraging efficient medium-term planning and safeguarding

\footnotetext{
${ }^{35}$ Hallerberg et al (2009), Von Hagen (2005) and de Haan et al. (1999) find support for the hypothesis that the comprehensiveness of the budget process improves fiscal discipline.

${ }^{36}$ Stapenhurst et al. (2008) looks at the range of models for engaging parliament in the budgeting process.

${ }^{37}$ Alesina et al. (1999) and Wehner (2009) demonstrate that limits on parliamentary amendment powers are positively associated with fiscal outcomes.

${ }^{38}$ One option to prevent supplementary budgets from being used to exceed spending caps is to agree on an annual supplementary budget provision within the binding spending caps agreed at the start of the government term. Finland has effectively used such an agreed procedure to cover both unexpected additional needs and fluctuations in appropriation levels, and investment in fixed-term stimulus measures during the economic crisis.
} 
implementation of the government's consolidation strategy. To avoid future expenditure room being taken up by binding contracts or future promises, controls on multi-annual commitments should also be in place.

\section{The credibility of the government's budgetary control framework depends on it being robust to the unforeseeable but inevitable shocks that arise in the course of implementing the consolidation program. Fiscal plans and budget frameworks should} make some explicit provision for unexpected expenditure pressures through an unallocated contingency reserve or a budget margin. Given the moral hazard they engender, it is critical that such reserves are governed by clear and rigorously enforced rules that limit their use to genuinely unforeseeable and unavoidable circumstances. ${ }^{39}$ If those contingency provisions prove inadequate, the executive should have the power to impose expenditure limitations during the budget execution to keep the consolidation program on track.

\section{EVALUATION OF BUDGET INSTITUTIONS IN SOUTHEASTERn EUROPEAN COUNTRIES}

\section{Box 2. Methodology for the Evaluation}

The ten budget institutions and their key features described in Section III are used to evaluate the institutional strength of each Southeastern European country. Each key feature is translated into a specific evaluation question. The number of questions by institution varies from three to six, and the assessment consists of 41 questions in total. The questions have been formulated in such a way that they are factually verifiable, and a country is given a rating of 0 if the criterion is not met; 1 if the criterion is partly met; and 2 if the criterion is fully met. The evaluation questions and basis for each rating are set out in Appendix I.

For every country, the ratings against each question are averaged to produce an overall score of the strength of each of the ten institutions. This value can range from A to F, in which: A is very strong (average rating of 2); $\mathrm{B}$ is strong (average rating of 1.5-2); $\mathrm{C}$ is moderately strong (1-1.5); D is moderately weak (0.5-1); E is weak $(0-0.5)$; and $\mathrm{F}$ is very weak (0). Individual country scores are compared against the average for the Southeastern European countries as a whole.

The ratings of each institution are then averaged globally and for each stage of the consolidation process (three institutions are linked to the understanding of the consolidation requirement, four to the definition of the strategy of consolidation, and three to its implementation). Each of the ten institutions has the same weight in these averages, regardless of the number of questions used to rate the institution.

The Southeastern European countries considered have diverse underlying fiscal governance arrangements. These factors make it difficult to put relative weights on the institutional aspects that are applicable for all countries. The decision not to make a priori judgments on the relative importance of institutions is also influenced by the recognition that consolidation needs differ across countries. Many of the institutions are interlinked and mutually reinforcing, making it difficult to highlight one as being more important than another. Finally, this type of survey cannot take fully into account the quality of different institutional arrangements; for example even if fiscal forecasts are being regularly done it tells us little about the quality of such forecasts.

${ }^{39}$ See Cebotari et al. (2009) for a discussion of the lessons from experience with contingency appropriations. 
36. The ten budget institutions described above provide the framework for an assessment of the institutional preparedness of Southeastern European countries for fiscal consolidation. The ten counties included in the evaluation are Albania, Bosnia and Herzegovina, Bulgaria, Croatia, Kosovo, FYR Macedonia, Moldova, Montenegro, Romania and Serbia. The methodology used in the evaluation is described in Box 2.

\section{A. Overall Strength of Budget Institutions}

37. The overall picture that emerges from the evaluation is one of similar overall strength of budget institutions across Southeastern European countries, but with significant variation in the strength of different institutions within each country (Table 1). ${ }^{40}$ On a scale of A to F, most countries have an overall score of C, with two D outliers. Within these overall results, the following patterns can be noted:

- Variation in institutional strength within countries was greater than that across countries.

- This suggests there is room for improvement in all countries. Only one country (Romania) scores moderately strong (C) or better for all ten institutions. No country scores moderately weak (D) or worse for all ten institutions;

- $\quad$ Average scores for the Southeastern European as a whole were in the moderately strong (C) to moderately weak (D) range for all institutions. The exception was independent fiscal agency (E), reflecting the fact that only three countries (Croatia, Romania, and Serbia) have established such agencies, and then only very recently;

- $\quad$ For all but one of the ten institutions, at least one country received a score of moderately strong (B), with three instances of very strong (A).

\footnotetext{
${ }^{40}$ The evaluation's focus on formal institutions gives an inherent advantage to those countries that codify budget practices through transparent mechanisms, such as organic budget laws, parliamentary standing orders, or published budget regulations over that that rely on established practices or informal "rules of the game."
} 
Figure 2. Average Scores-Southeastern Europe versus Selected EU Countries

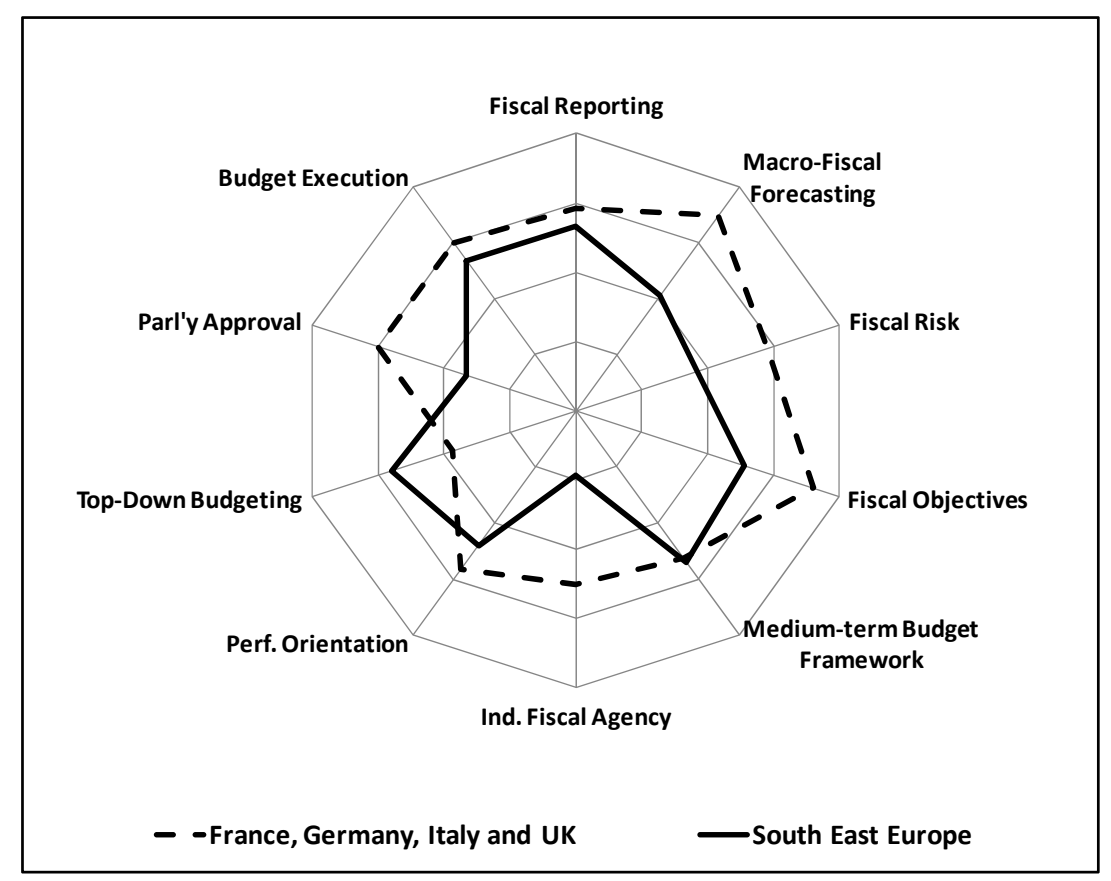

38. Basic fiscal reporting, medium-term budget framework, top-down budgeting, and budget execution emerge as areas of relative strength. Figure 2, which compares Southeastern European countries to the average of a selection of EU countries (France, Germany, Italy, UK), suggests that average institutional strength in these areas is close to or better than the standard set by the largest European countries. All 10 countries score C or better on fiscal reporting and budget execution - reflecting the significant focus on strengthening the basics in the last two decades - while 9 countries score $\mathrm{C}$ or better in medium-term budget framework and top-down budgeting - reflecting recent reforms in these related areas across the region. This suggests that in most Southeastern European countries the four basic pillars of fiscal policy-making, basic central government fiscal information, medium-term budget framework, top-down aggregate fiscal control, and strong budget execution, would appear to be largely in place. In practice, however, while most countries have introduced top-down expenditure targets on an aggregate and sectoral level, it is very common for these to be breached during final budget negotiations, which undermines the credibility of the MTBF.

39. At the same time, significant room for improvement exists in the areas of macrofiscal forecasting, fiscal risk, fiscal objectives, independent fiscal agencies and parliamentary approval. Of the ten Southeastern European countries: only four countries have relatively strong ( $\mathrm{C}$ or above) fiscal risk management; only three countries have established independent fiscal agencies; and only three countries have relatively strong parliamentary approval processes. Weaknesses in these institutions undermine the credibility of the budget, as well as the accountability of governments for the fiscal policies they pursue. 
Figure 3. Average and Range of Scores by Institution

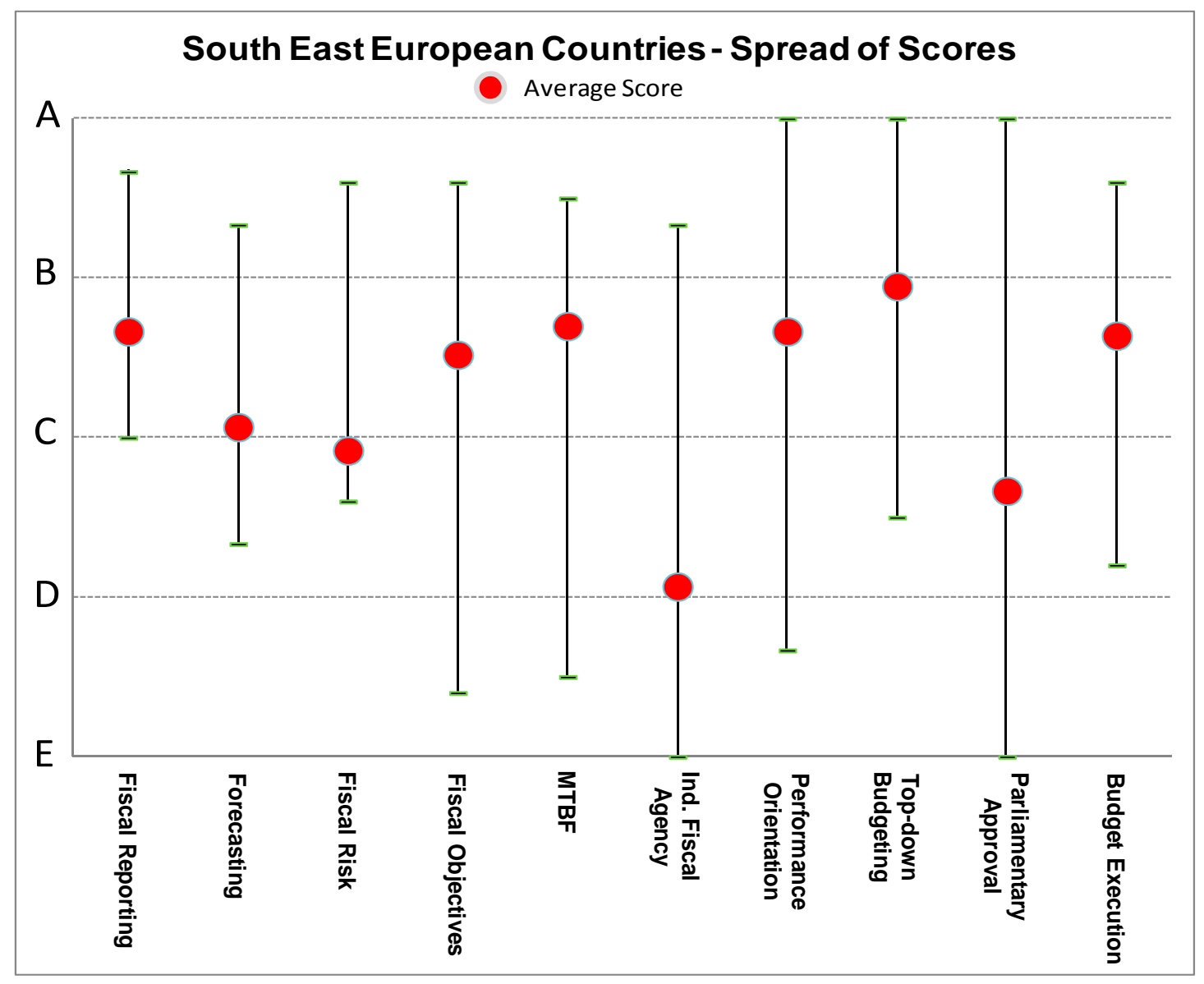


Table 1. Summary of Institutional Evaluation

\begin{tabular}{|c|c|c|c|c|c|c|c|c|c|c|c|}
\hline \multirow{2}{*}{ Budget Institutions } & \multirow{2}{*}{$\begin{array}{l}\text { SEE } \\
\text { Avg. }\end{array}$} & \multicolumn{10}{|c|}{ South East European Countries } \\
\hline & & Alb & $\mathbf{B i H}$ & Bul & Cro & Kos & Mac & Mol & Mon & Rom & Ser \\
\hline \multirow{4}{*}{\begin{tabular}{|ll} 
A. & Unde rs tanding the Fis cal Challenge \\
1 & Fiscal Reporting \\
2 & Macro-Fiscal Forecasting \\
3 & Fiscal Risk Management \\
\end{tabular}} & $\mathrm{C}$ & $\mathrm{C}$ & $\mathrm{C}$ & $\mathrm{C}$ & $\mathrm{C}$ & $\mathrm{C}$ & $\mathrm{C}$ & D & D & $\mathrm{C}$ & D \\
\hline & $\mathrm{C}$ & $\mathrm{B}$ & $\mathrm{B}$ & $\mathrm{C}$ & $\mathrm{B}$ & $\mathrm{B}$ & $\mathrm{C}$ & $\mathrm{C}$ & $\mathrm{C}$ & $\mathrm{C}$ & $\mathrm{C}$ \\
\hline & $\mathrm{C}$ & $\mathrm{C}$ & $\mathrm{D}$ & $\mathrm{C}$ & $\mathrm{C}$ & $\mathrm{C}$ & $\mathrm{D}$ & $\mathrm{C}$ & $\mathrm{C}$ & $\mathrm{B}$ & $\mathrm{C}$ \\
\hline & $\mathrm{D}$ & $\mathrm{D}$ & $\mathrm{C}$ & $\mathrm{C}$ & $\mathrm{D}$ & $\mathrm{D}$ & $\mathrm{C}$ & $\mathrm{D}$ & $\mathrm{D}$ & $\mathrm{C}$ & $\mathrm{D}$ \\
\hline \multirow{5}{*}{\begin{tabular}{|cl} 
B. & Developing a Cons olidation Plan \\
4 & Medium-term Fiscal Objectives \\
6 & Medium-term Budget Framework \\
5 & Independent Fiscal Agency \\
7 & Performance Orientation \\
\end{tabular}} & $\mathrm{C}$ & $\mathrm{C}$ & D & $\mathrm{C}$ & B & $\mathrm{C}$ & D & $\mathrm{C}$ & D & $\mathrm{C}$ & $\mathrm{C}$ \\
\hline & $\mathrm{C}$ & $\mathrm{C}$ & $\mathrm{E}$ & $\mathrm{B}$ & $\mathrm{C}$ & $\mathrm{B}$ & $\mathrm{C}$ & $\mathrm{C}$ & $\mathrm{D}$ & $\mathrm{B}$ & $\mathrm{B}$ \\
\hline & $\mathrm{C}$ & $\mathrm{B}$ & $\mathrm{B}$ & $\mathrm{B}$ & $\mathrm{B}$ & $\mathrm{B}$ & $\mathrm{C}$ & $\mathrm{B}$ & $E$ & $\mathrm{~B}$ & $\mathrm{C}$ \\
\hline & $E$ & $\mathrm{~F}$ & $\mathrm{E}$ & $\mathrm{F}$ & $\mathrm{C}$ & $\mathrm{F}$ & $\mathrm{F}$ & $\mathrm{F}$ & $\mathrm{F}$ & $\mathrm{C}$ & $\mathrm{B}$ \\
\hline & $\mathrm{C}$ & $\mathrm{B}$ & $\mathrm{D}$ & $\mathrm{B}$ & $\mathrm{A}$ & $\mathrm{C}$ & $\mathrm{C}$ & $\mathrm{C}$ & $\mathrm{C}$ & $\mathrm{C}$ & $\mathrm{E}$ \\
\hline \multirow{4}{*}{$\begin{array}{ll}\text { C. } & \text { Imple menting the Strat } \\
8 & \text { Top-Down Budgeting } \\
9 & \text { Parliamentary Approval } \\
10 & \text { Budget Execution }\end{array}$} & $\mathrm{C}$ & D & D & $\mathrm{C}$ & $\mathrm{C}$ & $\mathrm{C}$ & $\mathrm{C}$ & $\mathrm{C}$ & D & B & D \\
\hline & $\mathrm{C}$ & $\mathrm{C}$ & $\mathrm{B}$ & $\mathrm{B}$ & $\mathrm{A}$ & $\mathrm{C}$ & $\mathrm{C}$ & $\mathrm{B}$ & $\mathrm{D}$ & $\mathrm{B}$ & $\mathrm{C}$ \\
\hline & $\mathrm{D}$ & $\mathrm{D}$ & $\mathrm{F}$ & $\mathrm{C}$ & $\mathrm{D}$ & $\mathrm{E}$ & $\mathrm{B}$ & $\mathrm{D}$ & $\mathrm{D}$ & $\mathrm{A}$ & $\mathrm{D}$ \\
\hline & $\mathrm{C}$ & $\mathrm{C}$ & $\mathrm{C}$ & $\mathrm{C}$ & $\mathrm{C}$ & $\mathrm{B}$ & $\mathrm{C}$ & $\mathrm{B}$ & $\mathrm{C}$ & $\mathrm{C}$ & $\mathrm{C}$ \\
\hline OVERALL SCORE & $\mathrm{C}$ & $\mathrm{C}$ & D & $\mathrm{C}$ & $\mathrm{C}$ & $\mathrm{C}$ & $\mathrm{C}$ & $\mathrm{C}$ & D & $\mathrm{C}$ & $\mathrm{C}$ \\
\hline
\end{tabular}




\section{B. Overall Institutional Strength versus Consolidation Required}

\section{An indication of the relative urgency of institutional reform across Southeastern European countries can be derived by comparing the strength of each country's budget institutions with the level of fiscal stress now being placed on those institutions.} Comparing budget institutions and adjustment needs offer two possible interpretations; first, countries with robust (and sustained) institutional frameworks should, in principle, have smaller adjustment needs. In other words, strong institutions should enhance fiscal rigor and consequently reduce the need for fiscal adjustment in the first place (other things being equal). Second, countries could have large adjustment needs due to factors outside the influence of budget institutions but having strong institutions should increase the likelihood of planning and implementing a successful consolidation program.

\section{Fiscal conditions have rapidly deteriorated across Southeastern European} countries as a result of the crisis and some adjustment is required in almost all countries in the region. While the required adjustment is on average considerably lower for Southeastern European countries than for the advanced economies which have taken a bigger hit from the crisis, all of the countries in the region face considerable challenges. Figure 4 plots countries' overall institutional strength against the improvement in the structural primary balance between 2011 and 2020, based on current IMF estimates, required to lower general government gross debt to relevant thresholds. ${ }^{41}$ Based on the comparison:

- the relatively well populated upper-left quadrant suggests that those countries facing the smallest fiscal challenges have relatively strong budget institutions within this group of countries. As mentioned above, this is, in principle, what can be expected, but considerable risks in the fiscal outlook and major institutional vulnerabilities emphasize the need for further institutional reforms in the region;

- $\quad$ only two countries (Bosnia \&Herzegovina and Montenegro) find theirselves in the lower-right quadrant, facing a relatively large fiscal adjustment with relatively weak budget institutions.

\footnotetext{
${ }^{41}$ For Southeastern European countries, this threshold is defined as 40 percent of GDP. For countries significantly below their respective thresholds (Bulgaria, Macedonia FYR, Moldova, and Romania), the illustrative required adjustment is defined as the change in the primary balance between 2011 and 2020 needed to stabilize debt-to-GDP ratio at the end 2012 level by 2030, expressed as a percentage of GDP. Kosovo is excluded from this analysis. The estimates for required adjustment are only for illustrative purposes, not a policy recommendation for any of the countries. They also do not, for example, take into account projected growth of health and pension spending over the next two decades imposed by the population ageing. Further details on the methodology for this calculation are presented in IMF (2010a and 2010c). Source of data is WEO.
} 
Figure 4. Strength of Budget Institutions versus Illustrative Fiscal Adjustment Required

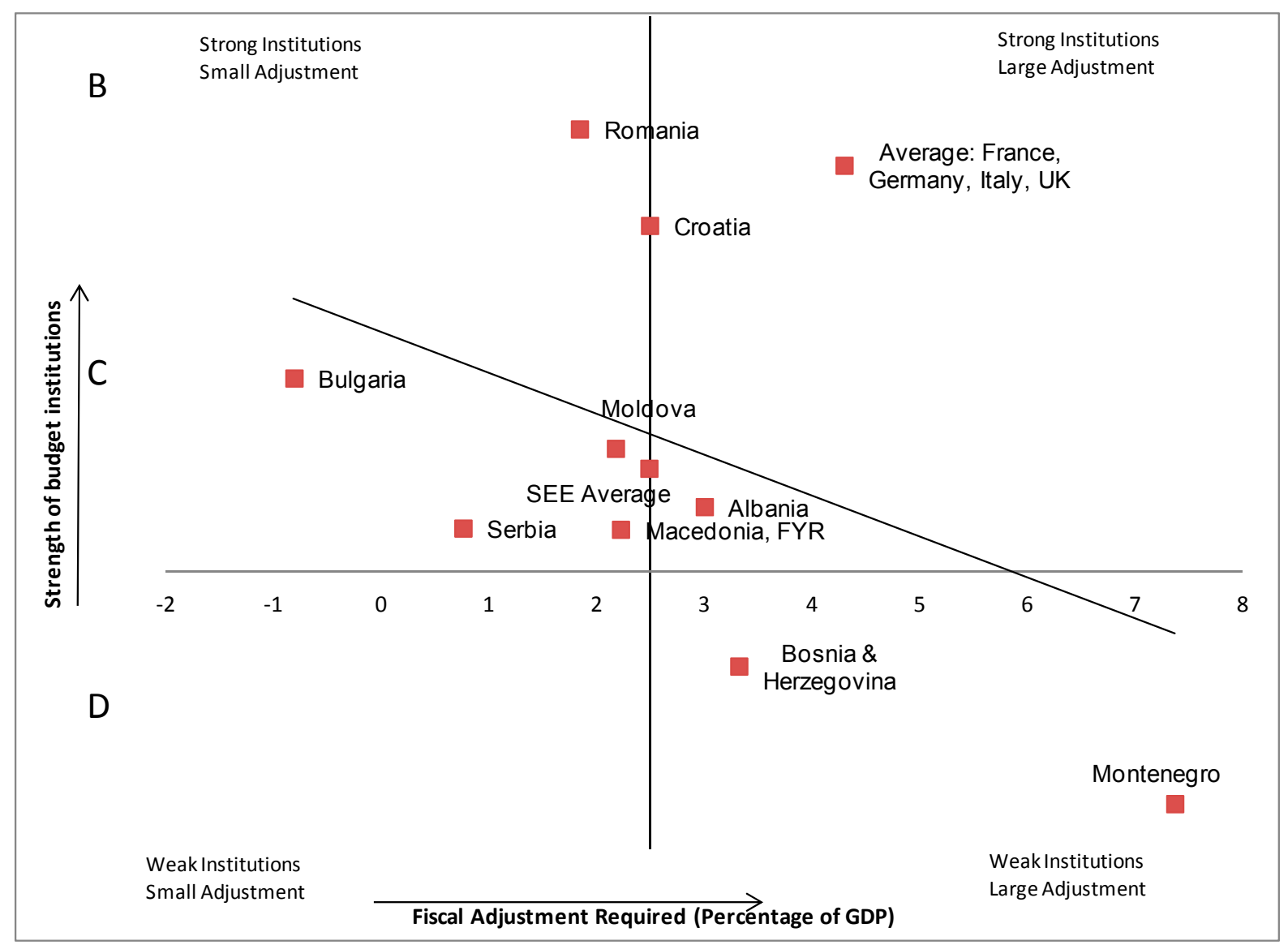

\section{Understanding the Fiscal Challenge}

42. While most Southeastern European countries have in place the fiscal reporting arrangements required to provide a reasonable picture of central government's present financial position, their understanding of future fiscal developments and the risks around those developments is less complete (Table 2). All countries score moderately strongly on fiscal reporting, with four countries (Albania, Bosnia \& Herzegovina, Croatia and Kosovo) scoring very strong. Most countries score moderately strong on macroeconomic and fiscal forecasting and one very strong (Romania). Fiscal risk disclosure and management appear to be an area of relative weakness for Southeastern European countries, with only four countries scoring moderately strong (Bosnia \& Herzegovina, Bulgaria, Macedonia FYR, and Romania). 


\section{Fiscal reporting}

43. The production of comprehensive and high quality fiscal reports is an area of relative strength among Southeastern European countries. However, there remain shortcomings, including:

- the production of comprehensive balance sheets in financial statements remains patchy across Southeastern European-countries;

- $\quad$ in only four countries (Albania, Bosnia \& Herzegovina, Kosovo, and Moldova) are central government financial statements published, audited, and certified within six months of the end of the financial year; and

- $\quad$ in only two countries (Montenegro, and Romania) do fiscal statistics cover the whole public sector, despite the continued prevalence of state-owned enterprises and banks in the region. ${ }^{42}$

\section{Fiscal forecasting}

44. While half the Southeastern European countries provide detailed multi-year macroeconomic and fiscal forecasts as part of their budget documentation, separation between current and new policy is rare and long-term fiscal projections are rare. This limits the ability of governments to demonstrate whether they are on track to meet their consolidation objectives. Specifically:

- $\quad$ half the countries (Albania, Croatia, Kosovo, Romania, and Serbia) regularly publish mid-year updates of their fiscal projections;

- $\quad$ only two countries (Montenegro ${ }^{43}$ and Moldova) routinely identify the fiscal impact of current versus new policies in their budget process; and

- $\quad$ only one country (Romania) prepares long-term fiscal projections.

\footnotetext{
${ }^{42}$ The assessment for Croatia and Kosovo may be too sanguine given that many state-owned enterprises are not fully covered by fiscal statistics.

${ }^{43}$ In the case of Montenegro, while new initiatives are separately identified during the budget process, anecdotal evidence would suggest that this is somewhat less than systematic.
} 
Table 2. Understanding the Fiscal Challenge

\begin{tabular}{|c|c|c|c|c|c|c|c|c|c|c|c|}
\hline \multirow{2}{*}{$\begin{array}{l}\text { Understanding } \\
\text { the Fiscal Challenge }\end{array}$} & \multirow{2}{*}{$\begin{array}{l}\text { SEE } \\
\text { Avg. }\end{array}$} & \multicolumn{10}{|c|}{ South East European Countries } \\
\hline & & Alb & $\mathrm{BiH}$ & Bul & Cro & Kos & Mac & Mol & Mon & Rom & Ser \\
\hline \multirow{7}{*}{$\begin{array}{l}\text { 1. Fiscal Reporting } \\
\text { a. Statements consolidate all CG } \\
\text { b. Statements include balance sheet } \\
\text { c. Statements audited \& certified } \\
\text { d. Statements published \& audited quickly } \\
\text { e. Statistics comprehensive } \\
\text { f. Stats indep. \& consistent w. int'l standard }\end{array}$} & C & B & B & C & B & B & C & C & C & C & C \\
\hline & $B$ & Fully & Partly & Partly & Fully & Fully & Fully & Partly & Fully & Fully & Partly \\
\hline & $\bar{D}$ & Partly & Partly & Not & Fully & Partly & Not & Not & Not & Partly & Partly \\
\hline & B & Fully & Fully & Fully & Fully & Fully & Partly & Partly & Fully & Partly & Fully \\
\hline & C & Fully & Fully & Partly & Partly & Fully & Partly & Fully & Not & Not & Partly \\
\hline & $\mathrm{C}$ & Partly & Partly & Partly & Fully & Fully & Partly & Partly & Fully & Fully & Partly \\
\hline & $\mathrm{C}$ & Partly & Fully & Fully & Fully & Partly & Partly & Fully & Not & Fully & Partly \\
\hline \multirow{4}{*}{$\begin{array}{l}\text { 2. Macro-Fiscal Forecasting } \\
\text { a. MT macro-fiscal forecast \& mid-year update } \\
\text { b. Separately identify current \& new policy } \\
\text { c. Long-term fiscal projections }\end{array}$} & $\bar{C}$ & C & D & $\bar{C}$ & $\bar{C}$ & $\bar{C}$ & D & $\bar{C}$ & $\bar{C}$ & B & C \\
\hline & B & Fully & Partly & Partly & Fully & Fully & Partly & Partly & Partly & Fully & Fully \\
\hline & C & Partly & Partly & Partly & Partly & Partly & Partly & Fully & Fully & Partly & Partly \\
\hline & $\mathrm{E}$ & Not & Not & Partly & Not & Partly & Not & Not & Not & Fully & Not \\
\hline \multirow{6}{*}{$\begin{array}{l}\text { 3. Fiscal Risk Management } \\
\text { a. Comprehensive risk statement } \\
\text { b. Parl. approves all new contingent liabilities } \\
\text { c. Alternative macro-fiscal scenarios } \\
\text { d. Risks to both assets \& liabilities analyzed } \\
\text { e. Tax expenditures reported \& controlled }\end{array}$} & $\bar{D}$ & $\bar{D}$ & $\bar{C}$ & $\bar{C}$ & $\bar{D}$ & $\bar{D}$ & $\bar{C}$ & D & $\bar{D}$ & $\bar{C}$ & $\bar{D}$ \\
\hline & $\mathrm{C}$ & Partly & Partly & Partly & Partly & Partly & Partly & Partly & Partly & Partly & Partly \\
\hline & $\mathrm{C}$ & Partly & Fully & Fully & Partly & Partly & Fully & Fully & Not & Fully & Partly \\
\hline & $\mathrm{D}$ & Not & Not & Partly & Partly & Partly & Fully & Not & Fully & Not & Partly \\
\hline & $\mathrm{C}$ & Partly & Partly & Partly & Partly & Partly & Fully & Not & Partly & Partly & Partly \\
\hline & $\mathrm{E}$ & Partly & Partly & Not & Not & Not & Not & Partly & Not & Partly & Not \\
\hline
\end{tabular}




\section{Fiscal risk management}

45. While fiscal risk statements have started to appear in the budget documentation of Southeastern European countries, quantification and control of fiscal risks are largely limited to formal government guarantees. In particular:

- discussion, quantification, and control of fiscal risks other than guarantees, such as public-private partnerships, litigation costs, and other contingent liabilities are found in five countries (Bosnia \& Herzegovina, Bulgaria, Macedonia FYR, Moldova, and Romania $)^{44}$;

- $\quad$ only two countries (Macedonia FYR and Montenegro) publish alternative fiscal scenarios as part of their annual budget documentation;

- $\quad$ while a majority of Southeastern European countries produce medium-term debt management strategies, only one country (Macedonia FYR) assesses the risks around both their asset and liability holdings; and

- none of the Southeastern European countries systematically monitor and report on tax expenditures, and only four countries (Albania, Bosnia \& Herzegovina, Moldova, and Romania) place some formal control on their size or growth.

\section{Developing a Consolidation Plan}

46. Most Southeastern European countries have the required institutions in place for planning a consolidation, but they lag behind on independent evaluation of fiscal objectives and forecasts (Table 3). While all but one country (Bosnia \& Herzegovina) states some kind of medium-term objective for fiscal policy, most countries do not have permanent fiscal rules. Medium-term budget frameworks have been also been established in all countries except Montenegro, though most countries use indicative as opposed to binding ceilings which limits their impact on future spending (and even in-year changes). Independent fiscal agencies are rare with the exeption of the recently established fiscal councils in Serbia, Romania, and Croatia. Performance-oriented reforms remain only partially implemented in most Southeastern European countries.

\section{Medium-term fiscal objectives}

47. Most Southeastern European countries articulate some medium-term fiscal objectives, but many of these are formulated in a manner that limits their effectiveness as a guide for fiscal policy making. Specifically:

\footnotetext{
${ }^{44}$ Disclosure of fiscal risks is currently limited to the central government of the Federation of Bosnia \& Herzegovina.
} 
- while all but one country express some objective for the evolution of the public finances beyond the budget year, in only half of cases is there a precise and transparent statement of both the targeted values for the fiscal aggregates and the time period for their achievement;

- $\quad$ in only one country (Bulgaria) have the fiscal objectives been expressed in the form of a stable fiscal rule; and

- $\quad$ while most countries have fiscal objectives that cover general government, only four (Croatia, Bosnia \& Herzegovina, Romania, and Serbia) have some kind of subnational fiscal rules and enforcement mechanisms needed to ensure that those national fiscal objectives are respected.

\section{Medium-term budget frameworks}

48. While nearly all Southeastern European countries situate their annual budgets within some form of detailed multi-year projections of revenue and expenditure, they do not generally impose binding constraints on future expenditure. Specifically:

- $\quad$ all Southeastern European countries produce detailed revenue and expenditure projections, with one exception, Montenegro, which produces more aggregated projections;

- while all countries fix multi-year objectives for aggregate expenditure, in only one country (Romania) do these take the form of ceilings which remain fixed for two or more years ${ }^{45}$; and

- typically there is no reconciliation of changes in sectoral or ministerial allocations from year to year. ${ }^{46}$

\section{Independent fiscal agencies}

49. With three very recent exceptions, independent fiscal agencies are generally absent in Southeastern European countries. In particular:

- where independent fiscal agencies have been established in Croatia, Romania, and Serbia, they mainly play an ex ante role in evaluating the credibility of macroeconomic forecasts and fiscal policies ${ }^{47}$; and

- $\quad$ only in Serbia does the fiscal council also evaluate fiscal performance ex post.

\footnotetext{
${ }^{45}$ In Bosnia \& Herzegovina while medium-term frameworks exist for the State, and the two entities (Republika Srpska and the Federation) they are not consolidated across the different government units.

${ }^{46}$ The reconciliation of changes is inadequate in Kosovo, suggesting that the assessment may be slightly optimistic.

${ }^{47}$ However, there are some questions regarding the independence of the Croatian fiscal council as it is chaired by the Ministry of Finance.
} 
Table 3. Developing a Consolidation Plan

\begin{tabular}{|c|c|c|c|c|c|c|c|c|c|c|c|}
\hline \multirow[t]{2}{*}{ Developing a Consolidation Plan } & \multirow{2}{*}{$\begin{array}{l}\text { SEF } \\
\text { Avg. }\end{array}$} & \multicolumn{10}{|c|}{ South East European Countries } \\
\hline & & Alb & $\mathrm{BiH}$ & Bul & Cro & Kos & Mac & Mol & Mon & Rom & Ser \\
\hline \multirow{6}{*}{$\begin{array}{l}\text { 4. Medium-term Fiscal Objectives } \\
\text { a. Objectives are precise \& transparent } \\
\text { b. Objectives are comprehensive } \\
\text { c. Report performance against objectives } \\
\text { d. Permanent fiscal rule } \\
\text { e. Sub-nat'l rules \& enforcement mechs }\end{array}$} & C & C & $E$ & B & C & B & C & C & D & B & B \\
\hline & $\mathrm{B}$ & Fully & Not & Fully & Partly & Fully & Partly & Fully & Partly & Fully & Fully \\
\hline & $B$ & Fully & Not & Fully & Fully & Fully & Partly & Fully & Partly & Fully & Fully \\
\hline & $\mathrm{B}$ & Fully & Partly & Fully & Fully & Fully & Fully & Fully & Partly & Fully & Fully \\
\hline & $\mathrm{D}$ & Partly & Not & Fully & Not & Not & Not & Not & Not & Partly & Partly \\
\hline & $\mathrm{C}$ & Not & Not & Not & Fully & Fully & Partly & Not & Partly & Fully & Fully \\
\hline \multirow{5}{*}{$\begin{array}{l}\text { 5. Medium-term Budget Frameworks } \\
\text { a. Multi-year spending \& revenue estimates } \\
\text { b. Binding multi-year expenditure ceiling } \\
\text { c. Clear statement of sectoral priorities } \\
\text { d. Covers majority of central government }\end{array}$} & C & B & B & B & B & B & C & B & $E$ & B & C \\
\hline & B & Fully & Fully & Fully & Fully & Fully & Fully & Fully & Partly & Fully & Fully \\
\hline & $\mathrm{C}$ & Partly & Partly & Partly & Partly & Partly & Partly & Partly & Not & Fully & Partly \\
\hline & $\mathrm{D}$ & Partly & Partly & Partly & Partly & Fully & Partly & Partly & Not & Partly & Not \\
\hline & B & Fully & Fully & Fully & Fully & Fully & Partly & Fully & Not & Fully & Partly \\
\hline \multirow{4}{*}{$\begin{array}{l}\text { 6. Independent Fiscal Agencies } \\
\text { a. Prepares macro \& fiscal forecasts } \\
\text { b. Evaluates ex ante fiscal policy } \\
\text { c. Evaluates ex post fiscal performance } \\
\end{array}$} & $E$ & $F$ & $E$ & $F$ & C & $F$ & $F$ & $F$ & $F$ & C & B \\
\hline & $E$ & Not & Partly & Not & Partly & Not & Not & Not & Not & Partly & Partly \\
\hline & $\bar{D}$ & Not & Not & Not & Fully & Not & Not & Not & Not & Fully & Fully \\
\hline & $E$ & Not & Not & Not & Partly & Not & Not & Not & Not & Partly & Fully \\
\hline \multirow{4}{*}{$\begin{array}{l}\text { 7. Performance Orientation } \\
\text { a. Program classification \& appropriation } \\
\text { b. Regularly monitored targets/objectives } \\
\text { c. Regular expenditure reviews }\end{array}$} & C & B & D & B & $A$ & C & C & C & C & C & $E$ \\
\hline & $C$ & Fully & Partly & Fully & Fully & Fully & Partly & Partly & Partly & Partly & Partly \\
\hline & $\mathrm{C}$ & Fully & Partly & Fully & Fully & Partly & Partly & Partly & Partly & Partly & Not \\
\hline & C & Partly & Not & Partly & Fully & Partly & Partly & Fully & Partly & Partly & Not \\
\hline
\end{tabular}




\section{Performance orientation}

50. Most Southeastern European countries have introduced some performance dimension into their budget processes, but only one has in place all the institutions needed to fully integrate performance information into budget decisions. Specifically:

- four countries (Albania, Bulgaria, Croatia, and Kosovo) use programs as the legal basis for expenditure appropriations, while the remaining countries include a program classification of expenditure in their budget documentation;

- while all but one country (Serbia) fix performance objectives or targets for some portion of their expenditure, in only two countries (Croatia and Moldova) are there regular, comprehensive reviews of program performance; and

- $\quad$ only one country (Croatia) has a comprehensive performance budgeting system which combines all of the above elements.

\section{E. Implementing the Consolidation Strategy}

51. While formal controls over the execution of the annual budget are relatively strong among most Southeastern European countries, parliamentary budget procedures tend to be relatively weak (Table 4). Most countries have adopted a top-down approach to budget preparation, and controls over budget execution are generally sound. However, the authority of the Ministry of Finance to defer or cut spending is weak, as its ability to control overspending is tenuous.

\section{Top-down budgeting}

52. The budget preparation process in most Southeastern European countries follows some kind of top-down procedure, but budgetary rigidities and circumvention of the annual budget process limits its impact on fiscal outcomes:

- all but two Southeastern European countries fix aggregate and/or sectoral ceilings on ministerial expenditure requests at the start of the annual budget process;

- however, in six countries, a substantial proportion of expenditure is subject to some form of revenue earmarking or standing commitments, which constrains the government's discretion in prioritizing expenditure to realize its fiscal objectives; and

- in three countries, major expenditure or revenue decisions are taken outside the annual budget process, raising a question about the ultimate effectiveness of these top-down procedures in restraining expenditure. 
Table 4. Implementing the Consolidation Strategy

\begin{tabular}{|c|c|c|c|c|c|c|c|c|c|c|c|}
\hline \multirow{2}{*}{ Implementing the Strategy } & \multirow{2}{*}{$\begin{array}{r}\text { SEE } \\
\text { Avg. }\end{array}$} & \multicolumn{10}{|c|}{ South East European Countries } \\
\hline & & Alb & $\mathrm{BiH}$ & Bul & Cro & Kos & Mac & Mol & Mon & Rom & Ser \\
\hline \multirow{5}{*}{$\begin{array}{l}\text { 8. Top-Down Budgeting } \\
\text { a. Agg. \& sectoral ceilings appproved at start } \\
\text { b. Agg. \& sectoral ceilings respected } \\
\text { c. Limited earmarking or statutory spending } \\
\text { d. All major fiscal decisions taken in budget } \\
\end{array}$} & C & C & B & B & $\bar{A}$ & C & C & B & D & B & C \\
\hline & B & Partly & Fully & Fully & Fully & Fully & Fully & Fully & Partly & Fully & Fully \\
\hline & C & Partly & Fully & Partly & Fully & Partly & Not & Fully & Not & Partly & Partly \\
\hline & C & Partly & Partly & Fully & Fully & Fully & Partly & Partly & Not & Fully & Not \\
\hline & $B$ & Fully & Partly & Fully & Fully & Not & Fully & Fully & Fully & Partly & Partly \\
\hline \multirow{4}{*}{$\begin{array}{l}\text { 9. Parliamentary Approval } \\
\text { a. Budget orientation debate \& vote } \\
\text { b. Clear limits on amendment power } \\
\text { c. Parl. approves budget from top-down } \\
\end{array}$} & D & D & $F$ & C & D & $E$ & B & D & D & $\bar{A}$ & D \\
\hline & $\mathrm{D}$ & Partly & Not & Not & Not & Partly & Partly & Not & Not & Fully & Partly \\
\hline & $\mathrm{C}$ & Not & Not & Partly & Fully & Not & Fully & Not & Fully & Fully & Partly \\
\hline & $\mathrm{D}$ & Partly & Not & Fully & Not & Not & Fully & Fully & Not & Fully & Not \\
\hline \multirow{6}{*}{$\begin{array}{l}\text { 10. Budget Execution } \\
\text { a. Overspending limited } \\
\text { b. Restrictions on carry-overs } \\
\text { c. Transparent contingency arrangements } \\
\text { d. MoF mandated to defer or cut spending } \\
\text { e. Multi-annual commitment controls } \\
\end{array}$} & C & C & C & C & C & B & C & B & C & C & C \\
\hline & C & Partly & Partly & Partly & Fully & Fully & Partly & Partly & Not & Partly & Partly \\
\hline & $B$ & Partly & Partly & Fully & Partly & Fully & Partly & Fully & Fully & Partly & Fully \\
\hline & $B$ & Fully & Fully & Fully & Fully & Fully & Fully & Fully & Partly & Fully & Fully \\
\hline & $\mathrm{D}$ & Not & Fully & Not & Partly & Partly & Not & Fully & Not & Partly & Partly \\
\hline & C & Partly & Partly & Fully & Partly & Fully & Partly & Fully & Fully & Fully & Not \\
\hline
\end{tabular}




\section{Parliamentary approval}

53. With one exception, parliamentary approval of the annual budget generally follows a conventional chapter-by-chapter rather than top-down sequence. Specifically:

- $\quad$ only in Romania does the legislature scrutinize the government's overall macroeconomic framework, economic policy, and fiscal objectives;

- four countries (Croatia, Macedonia FYR, Montenegro, and Romania) have introduced clear limits on parliament's power to amend the government's budget, but this is not the norm in the other Southeastern European countries; and

- the process of formally adopting the budget continues to follow a bottom-up procedure in five Southeastern European countries, while four countries (Bulgaria, Macedonia FYR, Moldova, and Romania) have moved to a top-down approval procedure.

\section{Budget execution}

54. Controls over budget execution are relatively strong in most Southeastern European countries, though in only two countries are governments obliged by law to propose offsetting cuts if expenditure exceeds budgeted levels. In particular:

- $\quad$ in all but one country (Montenegro) governments are required to seek legislative approval for any overspending, with two (Croatia and Kosovo) required to show how the overspending will be offset by savings;

- $\quad$ restrictions on carry-over of unspent appropriation exist in all countries, but in only half is there an explicit ceiling on total accumulation or drawdown of carry-overs;

- unallocated contingency reserves aimed at absorbing potential overspending of budgeted totals exist in all Southeastern European countries with clear rules on usage of the funds, with one exception (Montenegro);

- $\quad$ in only two cases (Bosnia \& Herzegovina and Moldova) is the finance minister authorized to spend less than the legally approved totals. In four countries this is limited to a fixed proportion of budget appropriations, while in the other four countries Parliamentary approval is required; and

- $\quad$ controls on line ministries' power to enter into multi-year expenditure commitments exist in all but one country (Serbia), but often apply only to capital expenditures. 


\section{STRENGTHENING BUdgetary InSTITUTIONS IN SOUTHEASTERN EUROPEAN COUNTRIES}

55. The analysis set out in Section IV shows considerable variance in the strengths and weaknesses of budget institutions across and within Southeastern European countries. Preparing budget institutions for the forthcoming period of consolidation will, therefore, require country-specific reform programs. The country-by-country evaluations on which this provisional assessment is based will of course need to be further refined before detailed reform recommendations for each Southeastern European country can be made based on their relative strengths and weaknesses. Nevertheless, the preceding analysis does highlight a number of common areas of institutional vulnerability which Southeastern European countries should seek to address as part of any comprehensive and coordinated fiscal consolidation strategy.

\section{A. Understanding the Fiscal Challenge}

56. Substantial improvements in fiscal reporting capacity have been made in most Southeastern European countries, but further strengthening is required if their consolidation efforts are to be based on a comprehensive and up-to-date understanding of the fiscal position. While most countries' financial statements consolidate all or the majority of general government institutions, only one publishes a full balance sheet. Audit arrangement are relatively strong, but lag in the production and publication of audited statements needs to be reduced to less than six months of this information is to feed into consolidation planning. Financial statistics also need to be expanded to encompass a wider range of institutions and transactions. The independence of statistical information also needs to be addressed with the majority of countries reporting partial or no independence.

57. Macroeconomic and fiscal forecasts in Southeastern European countries should identify more systematically the budgetary impact of policy changes and implications of alternative economic assumptions, including about the current cyclical position. All Southeastern European countries publish only a single "policy on" scenario for the evolution of the main macroeconomic and fiscal aggregates with most countries only partially differentiating between existing and new policy. In the context of a consolidation, this makes it difficult for the public to evaluate the adequacy of the government's policy actions and to hold government to account for their delivery. The reliance on a single macroeconomic scenario for both medium and long-term fiscal projections also makes it difficult for parliament and the public to assess the robustness of the government's consolidation program to a range of eventualities. This is of particular concern considering the potential impact of long-term demographic changes on health and pension costs in Southeastern Europe and the sensitivity of long term fiscal projections to different underlying assumptions. 
58. More rigorous accounting, reporting, and management of fiscal risks are required across Southeastern European countries to ensure that consolidation plans are not blown off course. None of the countries produce a comprehensive, quantified fiscal risk statement, and only five require all new contingent liabilities to be approved by parliament. None of the countries have established formal controls over tax expenditures and only four produce information on their costs. Contingent liabilities and tax expenditures have been shown to be major sources of fiscal leakage during previous consolidations, and should be subject to stricter monitoring and control arrangements than currently exist in most Southeastern European countries. Finally, given the complexity of government interventions in the financial sector - where uncertainties continue to persist - most Southeastern European countries also need to do more to demonstrate quantitatively that their consolidation plans are robust to a range of balance sheet risks.

\section{B. Developing a Consolidation Plan}

59. If they are to support effective consolidation planning and delivery, fiscal objectives need to be expressed and monitored in a manner which enables the public to hold the government to account for compliance. Most Southeastern European countries have comprehensive fiscal objectives in place, many of which are tied to the objective of either complying with European Union accession requirements, or for those countries that are already member states, adhering to the EU's Stability and Growth Pact. Most of the countries also regularly report on performance against their fiscal objectives, primarily in the form of regular submissions to Eurostat. Nevertheless, the majority of countries do not have a permanent numerical fiscal rule in place - this will need to change as adherence to numerical rules becomes obligatory for both EU member and EU candidate countries. Countries looking to express their fiscal objectives in the form of a permanent fiscal rule should ensure that they have in place the fiscal reporting, forecasting, and other planning institutions that are preconditions to the effective operation of rule-based fiscal policy-making. EU accession will also dictate that fiscal objectives cover general government and possibly in future the wider public sector, and this will require legal and institutional mechanisms that ensure subnational governments, and state-owned financial and nonfinancial enterprises, play their full part in their achievement.

60. Medium-term budget frameworks should impose binding restrictions on future budgets, and their coverage should be expanded. Medium-term budget frameworks should translate a country's long-term fiscal objectives into reliable projections of revenues and binding targets for expenditures and fiscal balances. However, the multi-year expenditure estimates produced by most Southeastern European countries are purely indicative and are revised on an annual basis without reconciliation. These countries should consider more binding multi-year aggregate and/or sectoral expenditure ceilings to limit the tendency for upwards drift in expenditure from one budget to the next. Among the minority of countries 
that do impose multi-year restrictions on future budgets, there is scope to expand the coverage of those restrictions to a larger proportion of central government expenditure

61. Independent fiscal agencies could play an important role in ensuring that consolidation strategies are based on credible forecasts and objectives ex ante and in evaluating the government's adherence to those strategies ex post. Over the last two to three years a few Southeastern European countries have started to use independent agencies to evaluate their ex ante forecasts and ex post performance, but their role is largely advisory and at an early stage of development. Given the tendency on the part of governments to rely on optimistic forecasts in order to understate the degree of consolidation required, there is a strong case for greater independent scrutiny of the macroeconomic assumptions and fiscal judgments that underpin a country's consolidation program. Furthermore, the conflicts of interest associated with governments assessing their own fiscal performance would strongly suggest the case for giving independent fiscal agencies a more exclusive mandate in this area. However, as with many small countries, the challenges of establishing a truly independent fiscal agency should not be underestimated.

62. If performance information is to contribute effectively to consolidation planning, it needs to be more effectively integrated into the budget process in most Southeastern European countries. Some Southeastern European countries now appropriate their budgets on a programmatic basis while most of the others are still at the early stages of this transformation. Key performance indicators for major programs have been developed in a number of countries but these indicators are rarely used to inform the budget planning process. And few countries undertake the kind of regular program monitoring and evaluation needed to ensure that program performance information is systematically used to improve the allocative and operational efficiency of expenditure. Further efforts in this area are essential, although the benefits may only become evident in the longer term.

\section{Implementing the Consolidation Strategy}

63. The lack of fiscal discipline inherent in the annual and medium-term budget process needs to be addressed if Southeastern European members are to deliver their consolidation plans. While budget preparation in most Southeastern European countries follows some kind of top-down approach, with sectoral ceilings being approved by government ex ante, these ceilings are rarely respected when the budget is delivered. The scope of budget discussions in many countries is still constrained by earmarking of revenues, statutory spending rigidities, or the existence of multiple laws stipulating government expenditure. In many countries, repeated recourse to supplementary budgets systematically undermines the credibility and finality of the initial top-down decision-making process. Southeastern European countries should therefore look to enforce aggregate and sectoral ceilings during budget preparation, remove revenue earmarks, and strictly limit supplementary budgets to expenditure-neutral changes in all but the most exceptional cases. 


\section{Southeastern European legislatures should play a more structured role in} scrutinizing and overseeing the implementation of the government's consolidation strategy. Legislative oversight of the fiscal consolidation strategy could be strengthened if parliamentarians were required to not just debate but also to endorse the government's medium-term fiscal objectives. Efforts to involve parliament early in the budget process have been promoted in recent years, but so far, with a couple of exceptions, little substantial reform has been witnessed in this area. Furthermore, the credibility of the government's consolidation plans would be strengthened if parliamentary voting started with a decision on the overall level of revenue and expenditure before moving on to individual budget chapters.

\section{While in-year cash management and budget execution controls are relatively} well developed in Southeastern European countries, contingency arrangements and controls over multi-annual commitments need to be strengthened. Over commitment against budgets has resulted in the accumulation of payment arrears in the region since the crisis began and under subsequent fiscal consolidations efforts. To counter this tendency, Southeastern European countries should tighten up their procedures for dealing with over commitment of expenditure and payment arrears and limit the upward drift in expenditure during budget execution. Measures could include increasing central contingency reserves or granting the central budget authority a broader mandate to impose expenditure reductions. To prevent ministries from circumventing in-year budget controls by entering into future unfunded expenditure commitments, countries should look to introduce or strengthen multiannual commitment controls. These measures should also target accumulation of payment arrears at local government level, given the general government focus of the fiscal consolidation effort. 


\section{Appendix I. Evaluation Framework}

\section{Understanding THE SCALE AND SCOPE OF THE Fiscal Challenge}

\section{Comprehensive, Timely and Credible Fiscal Reporting}

a. Do the central government annual financial statements consolidate all central government entities? Scoring: $0=$ no annual financial statements are produced; $1=$ annual financial statements cover only the budget; $2=$ annual financial statements cover all of central government.

b. Do central government annual financial statements include assets and liabilities? Scoring: $0=$ no balance sheet is produced; $1=$ a balance sheet is produced but not all assets or liabilities are included; $2=\mathrm{a}$ comprehensive balance sheet, which includes nonfinancial as well as financial assets, is prepared.

c. Are financial statements audited by an independent supreme audit institution? Does the auditor certify whether the statements represent a true and fair view of the government's overall financial position? Scoring: $0=$ no external audit is publicly available; $1=$ there is a published audit but the external auditor does not issue an overall opinion as to whether the statements represent a true and fair view of the government's financial position; $2=$ there is a published external audit in which the auditor gives an opinion as to whether the accounts represent a true and fair view of the government's financial position.

d. Are annual financial statements published and audited in a timely manner? Scoring: $0=$ financial statements are published more than 6 months after the end of the financial year; $1=$ financial statements are published but not audited within 6 months of the end of the financial year; $2=$ financial statements are published and audited within 6 months of the end of the financial year.

e. Are government financial statistics comprehensive? Scoring: $0=$ financial statistics are not produced or cover only central government; $1=$ financial statistics for central and general government are produced; $2=$ financial statistics for the whole of public sector are produced.

f. Are government financial statistics produced by an independent statistics office consistent with an international standard? Scoring: $0=$ neither, $1=$ produced by an independent office or in line with an international standard, but not both; $2=$ produced by an independent office and in line with SNA93, ESA95, or GFS2001.

\section{Robust Macroeconomic and Fiscal Forecasting}

a. Does the government publish medium-term macroeconomic and fiscal forecasts, inclusive of all major economic assumptions (e.g., GDP, inflation, exchange rate, oil price, unemployment)? Is there a mid-year update that is published? Scoring: $0=$ no MT projections published or published without assumptions; $1=$ government's 
medium-term projections published with assumptions, $2=$ both an annual and a midyear update of the projections and assumptions are published?

b. Do fiscal projections separately identify the impact of current versus new policies (revenue and expenditure measures)? Scoring: $0=$ no; $1=$ for some but not all new revenue and expenditure measures or no consolidated presentation of fiscal impact of new polices; $2=$ budget documents present a consolidated summary of the fiscal impact of all proposed new revenue and expenditure measures.

c. Are long-term fiscal projections (i.e., for at least 20 years) prepared by government and published periodically (i.e., at least every three years)? If yes, do they include the impact of demographic factors? Do they look at a range of demographic scenarios? Do they also look at other factors (e.g., health care costs) affecting long-term fiscal sustainability)? Scoring: $0=$ no long-term projections published or published infrequently (at intervals exceeding 3 years); $1=$ government publishes long-term budgetary projections at least every 3 years, but only on the basis demographic variables, $2=$ comprehensive long-term fiscal sustainability reports are prepared at least every 3 years, and look at either a range of demographic scenarios or utilize one or more additional factors (e.g. health care costs, climate change, etc.).

\section{Fiscal Risks Management}

a. Are main contingent liabilities (guarantees, international commitments, social commitments, PPPs, legal claims) discussed and where possible quantified, in the budget documents? Scoring: $0=$ contingent liabilities not discussed in the budget documents; $1=$ some discussion of fiscal risks in budget documents; $2=$ budget documentation includes a comprehensive and quantified fiscal risk statement.

b. Are new contingent liabilities subject to parliamentary approval? Scoring: $0=$ parliamentary approval is not sought for new contingent liabilities; $1=$ parliamentary approval is sought for new guarantees only; $2=$ parliamentary approval is sought for new guarantees and other significant, predictable and quantifiable contingent liabilities.

c. Are alternative medium-term budget scenarios presented in the annual budget documents? Scoring: $0=$ no alternative medium-term scenarios are discussed; $1=$ alternative medium term macroeconomic scenarios are discussed but their consequences for the major fiscal aggregates are not presented; $2=$ alternative medium-term scenarios and their implications for the main fiscal aggregates are presented as part of the annual budget documentation.

d. Are the risks associated with government assets examined at the same time as those relating to government debt and other liabilities? Scoring: $0=$ the government does not prepare a medium-term debt management strategy, nor assesses the risks associated with government assets; $1=$ the government prepares a medium-term debt management strategy, including analysis of debt-related risks, but does not include 
asset-related risks; $2=$ the government publishes a medium-term debt management strategy, including analysis of debt-related risks and risks from government assets, including financial assets.

e. Are major tax expenditures quantified and made publicly available annually, e.g., presented in the annual budget documentation? Is there a mechanism in place for controlling the size of tax expenditures? Scoring: $0=$ there is no quantification of tax expenditures and no control on their size; $1=$ there is periodic quantification of tax expenditures but no control on, or budgetary objective for, their size; $2=$ there is quantification and annual reporting of all major tax expenditures, and a control on, or budgetary objective for, their size.

\section{Developing a Credible Fiscal Consolidation Strategy}

\section{Clear and Transparent Medium-Term Fiscal Objectives}

a. Is there a precise and time-bound medium-term fiscal objective? Scoring: $0=$ neither the precise value nor time period for the fiscal target is is specified (or no objective); $1=$ either the precise value or time-period is specified; $2=$ both the precise value and time period are specified.

b. Is (are) the fiscal objective(s) comprehensive in scope? Scoring: $0=$ the fiscal objective covers only the central government budget (or no objective); $1=$ covers the central government; $2=$ covers most relevant parts of the general government and the public sector.

c. Does the government routinely report on performance against its fiscal objectives? Scoring: $0=$ there is no reporting against the government's fiscal objectives; $1=$ there is periodic, ad hoc reporting of the government's performance against its fiscal objectives; $2=$ the government reports performance against its fiscal objectives at least annually.

d. Are the fiscal objectives expressed in terms of a permanent numerical fiscal rule? Scoring: $0=$ no rule or it frequently changes; $1=$ a rule exists, and has been stable over the past 3 years; $2=$ the rule has been stable for more than 3 years.

e. Are sub-national governments subject to clear fiscal rules and centralized enforcement mechanisms? Scoring: $0=$ there are no fiscal rules for sub-national governments; $1=$ there are fiscal rules but no centralized sanctions or enforcement mechanisms; $2=$ there are fiscal rules and centralized sanctions or enforcement mechanisms in the event of non-compliance.

\section{Medium-term Budget Framework}

a. Is the annual budget prepared within a set of medium-term revenue and expenditure projections? Scoring: $0=$ there are no medium-term estimates of revenue or expenditure in the budget documentation; $1=$ budget documentation includes multi- 
year estimates of major categories of revenue and expenditure; $2=$ budget documentation includes multi-year estimates for each major revenue category and medium-term costings of expenditure by sector, ministry or program.

b. Are there binding multi-year restrictions on aggregate expenditure? Scoring: $0=$ there are no multi-year objectives or restrictions on aggregate expenditure; $1=$ there is an explicit multi-year objective for aggregate expenditure but it applies only to the forecast (which can subsequently be revised); $2=$ there is a binding multi-year restriction on the outturn for aggregate expenditure which remains fixed for at least two years.

c. Does the government provide a clear and consistent statement of its medium-term ministerial, sectoral or programmatic priorities within that overall ceiling? Scoring: $0=$ Detailed medium-term expenditure estimates are mechanistic projections; $1=$ detailed medium-term expenditure estimates reflect the government sectoral priorities but there is no reconciliation of changes in sectoral allocations from year to year; $2=$ the government provides detailed medium-term sectoral expenditure estimates with a full explanation of any changes from year to year.

d. Do multi-year expenditure restrictions cover the majority of central government expenditure? Scoring: $0=$ there are no multi-year expenditure restrictions or they cover less than 50 percent of central government expenditure; $1=$ the medium-term budget framework covers more than 50 percent of central government expenditure; $2=$ the medium-term budget framework covers more than 75 percent of central government expenditure.

\section{Independent Fiscal Agencies}

a. Is there an independent agencies responsible for producing or evaluating the macroeconomic and fiscal assumptions underpinning the budget? Scoring: $0=$ no independent projections are prepared; $1=$ an independent organization prepares either macroeconomic forecasts or fiscal forecasts, $2=$ an independent organization prepares both macroeconomic and fiscal forecasts.

b. Is there an independent agency charged with evaluating the government's ex ante fiscal objective and/or policy? Scoring: $0=$ no independent evaluation of the government's fiscal policy; $1=$ an independent organization evaluates the government's fiscal policy, but its advice is confidential to the executive; $2=a n$ independent organization evaluates the government's fiscal policy and its advice is published.

c. Is there an independent agency charged with evaluating the government's ex post performance against its fiscal targets or objectives? Scoring: 0=no independent ex post evaluation of government fiscal performance; $1=$ an independent organization evaluates the government's ex post fiscal performance, but its views is regarded as advisory only; $2=$ there is an independent organization that is charged with providing 
an authoritative evaluation (i.e., one that requires follow-up) of the government's performance against its fiscal targets, objectives or rules.

\section{Performance-Orientation of the Budget}

a. Does the budget include a program classification? Are programs the basis for legislative appropriation of expenditure? Scoring: $0=$ budget document does not include a program classification; $1=$ budget document includes a program classification for information but this is not the basis for legislative appropriation; $2=$ budget documentation includes program classification and this is the basis for legislative appropriation.

b. Are there objectives and targets associated with each major expenditure program? Is the achievement of performance objectives and targets monitored at least annually? Scoring: $0=$ there are no performance objectives or targets for expenditure; $1=$ performance targets or objectives are established but not systematically monitored; $2=$ performance targets and objectives are set with systematic reporting on progress on at least an annual basis.

c. Are there comprehensive sector reviews on a regular basis? Scoring: $0=$ expenditure reviews are not part of the budget process; $1=$ expenditure reviews are infrequent or incomplete (rolling reviews are not complete or comprehensive reviews are ad hoc and/or happen more than every 3 years); $2=$ all expenditure programs are systematically reviewed on either a comprehensive (at least once every three years) or rolling basis (at least $20 \%$ per year).

\section{ImPlementing The Consolidation StRAtegy THROUgh THE BUdget Process}

\section{Top-Down Approach to Budget Preparation}

a. Is a limit on aggregate expenditure and the allocation to broad sectors or to ministries proposed by the Ministry of Finance and approved by Cabinet before the discussion of the detailed allocations? Scoring: $0=$ there are no ex ante limits on annual spending at the early stages of budget preparation within the Executive; $1=$ there are ex ante limits on aggregate expenditures; 2 = there are ex ante limits on both aggregate and sectoral/ministerial spending provided in budget submissions.

b. Are aggregate limits and sector or ministry allocations respected in the preparation of the budget within the Executive? Scoring: $0=$ ex ante ceilings are not respected; $1=$ ex ante ceilings are sometimes respected; $2=$ ex ante ceilings are almost always respected.

c. Is earmarking of revenue to expenditure or standing spending commitments relatively limited? Scoring: $0=$ more than 30 percent of central government revenue is subject to earmarking or standing spending commitments; $1=$ between 10 and 30 percent of central government revenue is subject to earmarking or standing spending 
commitments; $2=$ less than 10 percent of central government revenue is subject to earmarking or standing spending commitments.

d. Are all major revenue or expenditure decisions taken as part of the annual budget process? Scoring: $0=$ major revenue or expenditure decisions are often taken outside the budget process; $1=$ major revenue and expenditure decisions are sometimes taken outside the budget process; $2=$ major revenue and expenditure decisions are hardly even taken outside the budget process.

\section{Constraints on Parliamentary Budget Approval}

a. Do institutional arrangements ensure ownership of the medium-term fiscal strategy by the parliament? Scoring: $0=$ there is no separate budget orientation debate and parliament does not endorse a medium-term fiscal target or objective; $1=$ there is either a separate budget orientation debate or parliament endorses a medium-term fiscal target or objective strategy, but not both; $2=$ there is a separate budget orientation debate and parliament explicitly endorses a medium-term fiscal target or objective.

b. Are there limits on the legislature's right to amend the government's draft budget? Scoring: $0=$ there are no limits on the right of parliament to amend the draft budget; $1=$ parliament can introduce fiscally neutral amendments to the budget; 2 =parliament can change the composition of expenditures, but not increase the proposed budget deficit, nor total expenditures (alternatively, parliament must approve the government's proposed budget, without any modification).

c. Is the annual budget approved in a top-down sequence? Scoring: $0=$ parliament does not first approve an overall annual budget framework for total revenues and total expenditures; $1=$ parliament first approves an overall annual fiscal framework, but subsequent changes in budget aggregates are still possible; $2=$ parliament first approves an overall annual fiscal framework, then votes on the detailed expenditures within the approved top down constraints on total spending and revenue.

\section{Constrained Flexibility in Budget Execution}

a. Are there restrictions on overspending during the execution of the annual budget?

Scoring: $0=$ the government is not required to go back to parliament before the end of the current fiscal year when spending exceeds annual appropriations; $1=$ the government is required to submit a supplementary budget to parliament if spending exceeds annual appropriations; $2=$ in case of overspending against the annual appropriation, the government is required to submit a supplementary budget showing how overspending will be offset through reductions in other appropriations.

b. Are there restrictions on carried-over appropriations? Scoring: $0=$ there are no restrictions on carried-over appropriations; $1=$ there are restrictions on the types of expenditure subject to carry-over appropriations, but no limit on the size of carried- 
over balances into subsequent years or draw-down; $2=$ there are no carry-overs or the government imposes a ceiling on the size of annual carry-over or on carry-over drawdowns.

c. Are there contingency arrangements? Scoring: $0=$ no contingency arrangements: $1=$ there are contingency arrangements for specific expenditure categories; $2=$ there is a sizeable general contingency reserve (e.g., 1 to 3 percent of total expenditure) in the annual budget, with clear rules for which expenditure the reserve can be used.

d. Is the finance minister (the executive) mandated to defer or cut expenditure, i.e., not fully implement the approved budget? Scoring: $0=$ expenditures cannot be deferred or cut without prior approval of Parliament; $1=$ expenditures can be deferred or cut, without prior approval of Parliament, up to a certain limit; $2=$ budget appropriations can be deferred or cut, without limit.

e. Are there limits or controls on a line ministry's ability to enter into multi-annual expenditure commitments? Scoring: $0=$ there no limits or controls on multi-annual expenditure commitments; $1=$ there are limits or controls on some categories of multiannual expenditure commitments; $2=$ there are comprehensive limits or controls on all types of multi-annual expenditure commitments. 


\section{REFERENCES}

Alesina, Alberto, Ricardo Hausmann, Rudolf Hommes, and Ernesto Stein, 1999, "Budget Institutions and Fiscal Performance in Latin America," Journal of Development Economics, Vol. 59, pp. 253-273.

Balassone, Fabrizio, Daniele Franco, and Stefania Zotteri, 2007, "The Reliability of EMU Fiscal Indicators: Risks and Safeguards," Bank of Italy discussion paper (Temi di discussione del Servizio Studi), No. 633 (June).

Calmfors, Lars and Simon Wren-Lewis, 2011, "What Should Fiscal Councils Do?", Department of Economics Discussion Paper Series, University of Oxford, No. 537 (February).

Cottarelli, Carlo and José Viñals, 2009, "A Strategy for Renormalizing Fiscal and Monetary Policies in Advanced Economies," IMF Staff Position 09/22, (Washington: International Monetary Fund).

Crain, M.W, and J. Brian O'Roark, 2004, “The Impact of Performance-Based Budgeting on State Fiscal Performance,” Economics of Governance, Vol. 5, No. 2, pp. 167-186.

Curristine, Teresa, 2007, "Experience of OECD Countries with Performance Budgeting," in Marc Robinson (ed.) Performance Budgeting: Linking Funding and Results (Washington: International Monetary Fund).

Debrun, Xavier, Laurent Moulin, Alessandro Turrini, Joaquim Ayuso-i-Casals, and Manmohan S. Kumar, 2008, "Tied to the Mast? National Fiscal Rules in the European Union," Economic Policy April 2008, pp. 297-362.

- David Hauner, and Manmohan Kumar, 2009, "Independent Fiscal Agencies," Journal of Economic Surveys, Vol. 23, No. 1, pp. 44-81.

European Commission, 2006, Public Finances in the EMU, (Brussels).

— 2007, Public Finances in the EMU, (Brussels).

— 2010, Public Finances in the EMU, (Brussels).

—, 2011, Public Finances in the EMU, (Brussels). 
Everaert, Greetje, Manal Fouad, Edouard Martin, and Ricardo Velloso, 2009, "Disclosing Fiscal Risk in the Post-Crisis World," IMF Staff Position Note 09/18 (Washington: International Monetary Fund).

Gleich, Holger, 2003, "Budget Institutions and Fiscal Performance in Central and Eastern European Countries," European Central Bank Working Paper No. 215.

Guichard, Stephanie, Mike Kennedy, Echkard Wurzel, and Christophe Andre, 2007, "What Promotes Fiscal Consolidation: OECD Country Experience," OECD Economic Department Working Paper No. 553, (Paris: Organization for Economic Cooperation and Development).

Gupta, Sanjeev, Emanuele Baldacci, Benedict Clements, and Erwin R. Tiongson, 2005, "What Sustains Fiscal Consolidations in Emerging Market Countries?", International Journal of Finance and Economics No. 10, pp. 307-321.

De Haan, Jakob, Wim Moessen, and Bjorn Volkerink, 1999, "Budgetary ProceduresAspects and Changes: New Evidence for Some European Countries," in James Poterba and Jürgen von Hagen (eds.) Fiscal Institutions and Fiscal Performance, Chicago University Press.

Hallerberg, Mark, Rolf Strauch, and Jürgen von Hagen, 2004, "The Design of Fiscal Rules and Forms of Governance in European Union Countries," European Central Bank Working Paper No. 419.

—_ Rolf Strauch, and Jürgen von Hagen, 2009, "Fiscal Governance: Evidence from Europe”. Cambridge: Cambridge University Press, 2009 and Jürgen von Hagen, 1997, “ Electoral Institutions, Cabinet Negotiations, and Budget Deficits Within the European Union,” CEPR, No. 155. and Sami Yläoutinen, 2010, "Political Power, Fiscal Institutions and Budgetary Outcomes in Central and East European Countries", Journal of Public Policy 30:1, 2010.

International Public Sector Accounting Standards Board (IPSASB), 2009, "Reporting on the Long-Term Sustainability of the Public Finances," Consultation Paper (November).

IMF, 2004, "Government Guarantees and Fiscal Risk," Fiscal Affairs Department, $\mathrm{SM} / 05 / 120$ (Washington).

__, 2007, Manual on Fiscal Transparency, Fiscal Affairs Department (Washington). 
2009a, "Crisis-Related Measures in the Financial System and Sovereign Balance Sheet Risks," paper prepared by the Fiscal Affairs and Monetary and Capital Markets Departments (Washington).

— 2009b, "The State of Public Finances Cross-Country Fiscal Monitor: November 2009," Fiscal Affairs Department (Washington).

_ , 2009c, "Fiscal Rules: Anchoring Expectations for Sustainable Public Finances," Fiscal Affairs Department, SM/09/274 (Washington).

_- 2010a, "Navigating the Fiscal Challenges Ahead", IMF Fiscal Monitor, May (Washington).

— , 2010b, "Fiscal Exit: From Strategy to Implementation”, IMF Fiscal Monitor, November (Washington).

— 2010c, "Strategies for Fiscal Consolidation in the Post-Crisis World," Fiscal Affairs Department, SM/10/11 (Washington).

— 2011a, "Staying the Course on Fiscal Adjustment", IMF Fiscal Monitor Update, June (Washington).

2011b, “Addressing Fiscal Challenges to Reduce Economic Risks", IMF Fiscal Monitor, September (Washington).

Larch, Martin and M. Salto, 2005, "Fiscal Rules, Inertia, and Discretionary Fiscal Policy," Applied Economics Vol. 37, pp. 1135-1146.

— , and Martin Larch, 2004, "Improving Fiscal Policy in the EU: The Case for Independent Forecasts," European Economy Economic Papers No. 201, (Brussels: European Commission).

— 2006, "Fiscal Policy in the EU: Are Official Output Forecasts Biased?," Economic Policy (July).

Ljungman, Gösta, 2009, “Top-Down Budgeting-An Instrument to Strengthen Budget Management," IMF Working Paper 09/243 (Washington: International Monetary Fund).

Kopits, George and Steven Symansky, 1998, "Fiscal Policy Rules" IMF Occasional Paper, No. 162 (Washington: International Monetary Fund). 
Milesi-Ferretti, Gian Maria and Kenji Moriyama, 2004, "Fiscal Adjustment in EU Countries: A Balance Sheet Approach,” IMF Working Paper 04/143.

OECD, 2004, Best Practice Guidelines_-Off Budget and Tax Expenditures, (Paris).

—, 2007a, Economic Outlook, chapter "Fiscal Consolidation: Lessons From Past Experience", No. 81, June.

- 2007b, Performance Budgeting in OECD Countries.

Perotti, Roberto, 1998, “The Political Economy of Fiscal Consolidations,” Scandinavian Journal of Economics, 100(1), pp. 367-394.

Reddick, Christopher, 2003, "Testing Rival Theories of Budgetary Decision Making in the United States," Financial Accountability and Management, 19(4), pp. 315-340.

Robinson, Marc, 2007, “Results Information,” in Marc Robinson (ed.) Performance Budgeting: Linking Funding and Results, (Washington: International Monetary Fund).

— Review of the Empirical Literature," IMF Working Paper 05/210 (Washington: International Monetary Fund).

Rogoff, Kenneth .S. and J. I. Bertelsmann, 2010, “The Rationale for Fiscal Policy Councils: Theory and Evidence", Paper to Conference on Independent Fiscal Institutions, March 18-19, Fiscal Council Republic of Hungary, Budapest.

Strauch, Rolf, Mark Hallerberg, and Jürgen von Hagen, 2004, "Budgetary Forecasts in Europe: The Track Record of Stability and Convergence Programs," European Central Bank Working Paper No. 307.

Stapenhurst, Richard, Riccardo Pelizzo, David M. Olson, and Lisa von Trapp eds., 2008, Legislative Oversight and Budgeting (Washington: World Bank).

Tsibouris, George C., Mark A. Horton, Mark J. Flanagan, and Wojciech S. Maliszewski, 2006, "Experience with Large Fiscal Adjustments," IMF Occasional Paper No. 246, (Washington: International Monetary Fund). 
Von Hagen, Jürgen, 1992, "Budgeting Procedures and Fiscal Performance in the European Communities," European Commission Economic Papers No. 96, (Brussels: European Commission).

— , 2005, "Fiscal Rules and Fiscal Performance in the EU and Japan," CEPR Discussion Paper No. 5330.

— IMF Working Paper 96/78 (Washington: International Monetary Fund).

Wagschal, Uwe and Georg Wenzelburger, 2008, "Road to Success: Budget Consolidation in OECD Countries," Journal on Public Policy, Vol. 28, No. 3, pp. 309-339.

Wehner, Joachim, 2009, “Institutional Constrains on Profligate Politicians: The Conditional Effect of Partisan Fragmentation on Budget Deficits," Comparative Political Studies, DOI: 10.1177/0010414009347828, SAGE Publications.

Wyplosz, Charles, 2008, “Fiscal Policy Councils: Unlovable or Just Unloved?” Swedish Economic Policy Review No. 15, pp.11-30.

Yläoutinen, Sami, 2004, "Fiscal Frameworks in the Central and Eastern European Countries, Ministry of Finance, Finland, Discussion Paper No. 72. 